
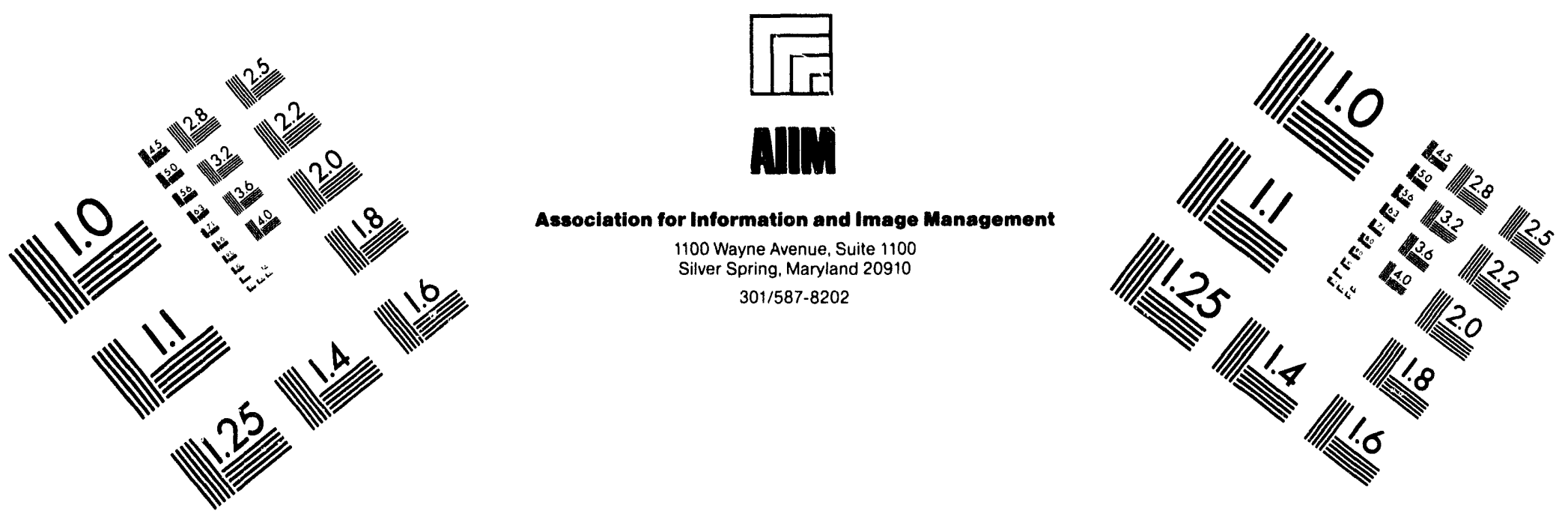

Centimeter

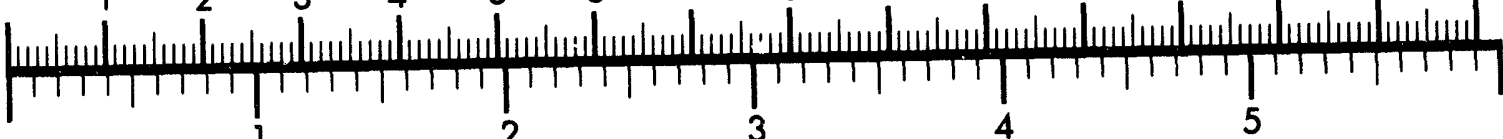
Inches
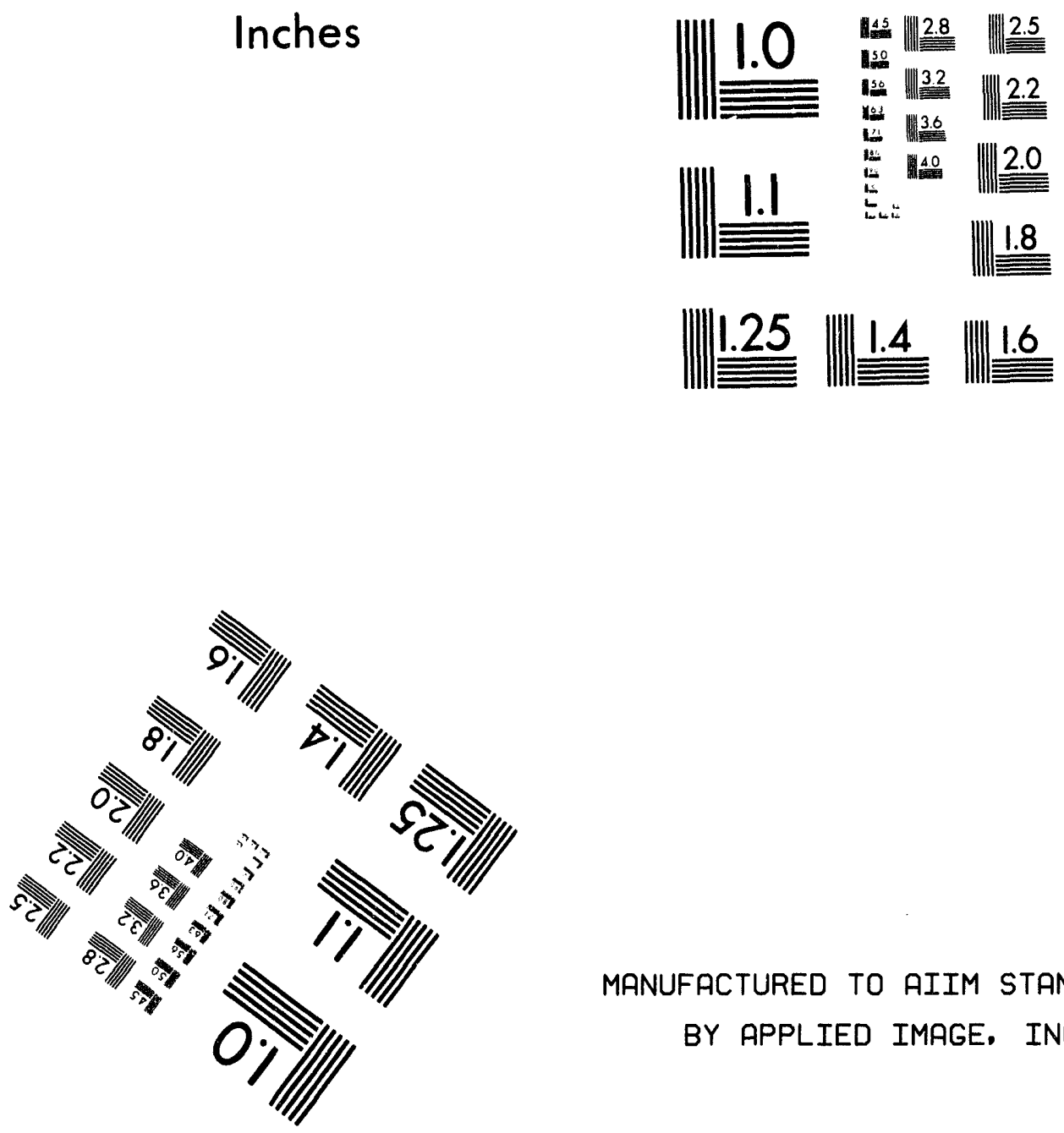

MANUFACTURED TO AIIM STANDARDS

BY APPLIED IMAGE, INC.

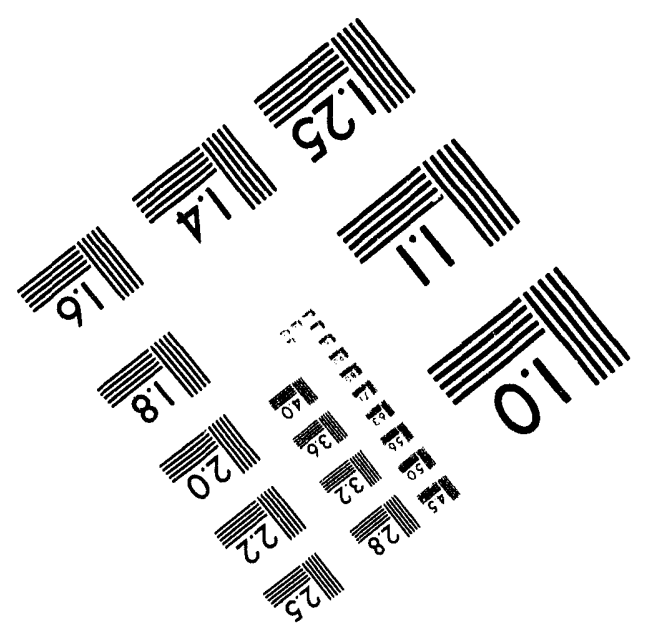



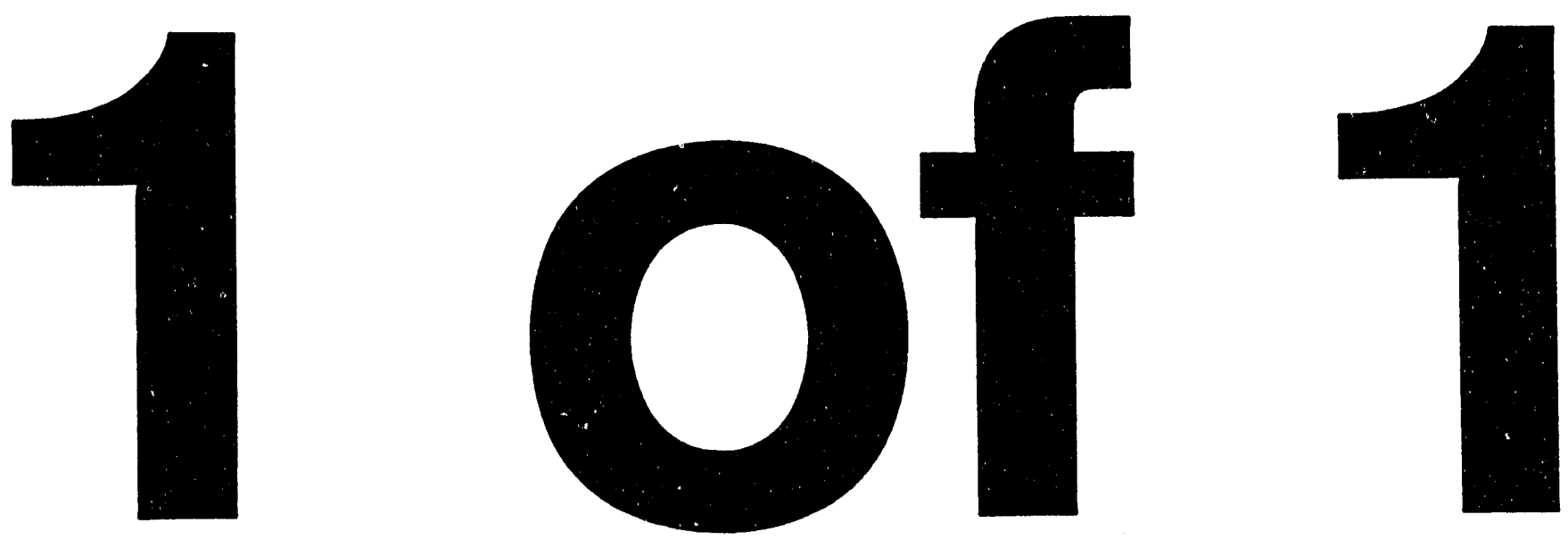
WHC-MR-0452

Addendum 1

\section{A Brief History of the T Plant Facility at the Hanford Site}

M. S. Gerber, PhD

Date Published

May 1994

Prepared for the U.S. Department of Energy Office of Environmental Restoration and Waste Management

\footnotetext{
(28) Westinghousa

P.O. Box 1970

Hanford Company Richland, Washington 99352

Hanford Operations and Engineering Contractor for the

U.S. Department of Energy under Contract DE-AC06-87RL 10930
} 


\section{RELEASE AUTHORIZATION}

Document Number: WHC-MR-0452, Addendum 1

Document Title: A Brief History of the T Plant Facility at the Hanford Site

Release Date: May 16, 1994 .

$* * * * * * * * * * * * *$

This document was reviewed following the procedures described in WHC-CM-3-4 and is: APPROVED FOR PUBLIC RELEASE

$* * * * * * * * * * * * *$

WHC Information Release Administration Specialist: MN Boston

Th. Bcstar

$5 / 10 / 94$

(Signature)

(Date) 
Document Title: A BRIEF HISTORY OF THE T PLANT FACILITY AT THE HANFORD SITE

Prepared by:

Reviewed by:

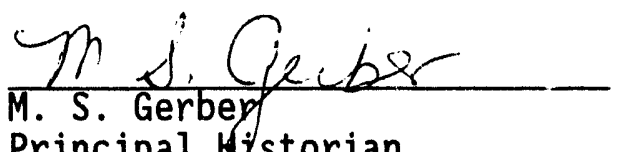

Principal kistorian

Approved by:

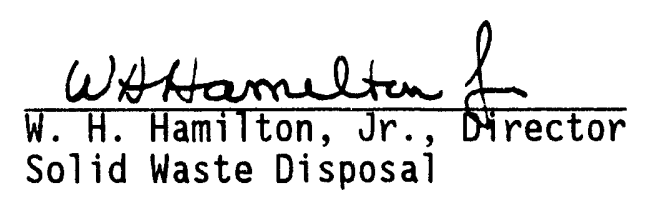

$\frac{5-9-44}{\text { Date }}$

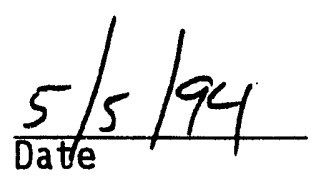

$\frac{5: 12 / 94}{\text { Date }}$ 
WHC-MR-0452, ADDENDUM 1

This page intentionally left blank. 


\section{CONTENTS}

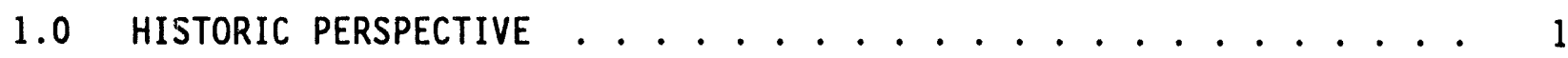

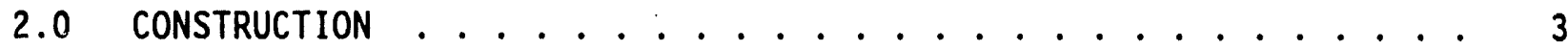

3.0 PERSONNEL AND TRAINING .................. 5

4.0 CELL STRUCTURE AND USAGE .................. 7

5.0 ORIGINAL SEPARATIONS PROCESS ............... 11

6.0 SUPPORT AND ANCILLARY STRUCTURES ASSOCIATED WITH

7.0 EARLY OPERATING EXPERIENCE . . . . . . . . . . . . . 17

8.0 EARLY PROCESS CHANGES . . . . . . . . . . . . . . 19

9.0 SEMIWORKS MISSIONS .................. 21

10.0 WASTE Management . . . . . . . . . . . . . . . 23

11.0 ATMOSPHERIC RELEASES AND HAZARD CONTROL . . . . . . . . . . 25

12.0 T PLANT'S TRANSITION: THE END OF THE CHEMICAL PROCESSING MISSION ............... 35

13.0 CONTAMINATION EVENTS . . . . . . . . . . . . . . 37

14.0 T PLANT'S ROLE AS A DECONTAMINATION FACILITY . . . . . . . . . 39

15.0 1990s BRING NEW CHALLENGES AND OPPORTUNITIES TO T PLANT . . . . . 41

16.0 REFERENCES . . . . . . . . . . . . . . . . 47

17.0 BIBLIOGRAPHY . . . . . . . . . . . . . . . . 55 


\section{LIST OF TERMS}

$\begin{array}{ll}\text { AEC } & \text { U.S. Atomic Energy Commission } \\ \text { BiPO } & \text { bismuth phosphate } \\ \text { CAM } & \text { Continuous Air Monitor } \\ \text { CWS } & \text { Chemical Warfare Service } \\ \text { DOE } & \text { U.S. Department of Energy } \\ \text { duPont } & \text { E.I. duPont de Nemours Corporation } \\ \text { ECN } & \text { engineering change notice } \\ \text { ECOlogy } & \text { Washington State Department of Ecology } \\ \text { G.E. } & \text { General Electric } \\ \text { HEPA } & \text { high-efficiency particulate air (filter) } \\ \text { HEW } & \text { Hanford Engineer Works } \\ \text { H.I. } & \text { Health Instruments } \\ \text { HW } & \text { Hanford Works } \\ \text { KMnO } & \text { potassium permanganate } \\ \text { MED } & \text { Manhattan Engineer District } \\ \text { NCRP } & \text { National Committee on Radiation Protection } \\ \text { OSD } & \text { Operating Specifications Document } \\ \text { P } & \text { Production } \\ \text { PUREX } & \text { Plutonium-Uranium Extraction (Plant) } \\ \text { PWR } & \text { pressurized water reactor } \\ \text { REDOX } & \text { Reduction-Oxidation (Plant) } \\ \text { S } & \text { Separations } \\ \text { SAR } & \text { Safety Analysis Report } \\ \text { SDS } & \text { Submerged Demineralized System } \\ \text { SMX } & \text { Clinton Semiworks } \\ \text { SST } & \text { single-shell tanks } \\ \text { TC } & \text { temporary construction } \\ \text { TRUSAF } & \text { Transuranic Storage and Assay Facility } \\ \text { WHC } & \text { Westinghouse Hanford Company } \\ & \end{array}$




\section{A BRIEF HISTORY OF THE T PLANT FACILITY \\ AT THE HANFORD SITE}

\subsection{HISTORIC PERSPECTIVE}

$T$ Plant (221-T) was the first and largest of the early chemical separations plants at the Hanford Engineer Works (HEW) (World War II name for the Hanford Site). Officially designated as a Cell Building by the Manhattan Engineer District (MED) of the Army Corps of Engineers (agency responsible for HEW), T Plant served as the headquarters of chemical processing operations at Hanford from its construction until the opening of the REDOX Plant in January 1952. Because it formed a crucial link in the first, full-scale plutonium production operations in world history, it meets criteria established in the National Historic Preservation Act of 1966 as a National Historic Structure. 
WHC,-MR-0452, ADDENDUM 1

This page intentionally left blank. 


\subsection{CONSTRUCTION}

Ground was broken for $\mathrm{TPl}$ ant on June 22, 1943, and the first temporary construction (TC) support structure to be completed was a $24 \mathrm{ft}$ by $40 \mathrm{ft}$ wood frame structure that housed the offices of the Division Engineer. Finished on October 23, 1943, this small facility held the essential construction offices until a larger office building was completed midway between the $T$ and $U$ Plant sites. Field communication services (temporary telephone facilities) were not connected until December 12, 1943. Water for construction purposes was obtained from the preSite McGee Artesian Well beginning on November 8, 1943. However, only $200 \mathrm{gal} /$ minute at 20 pounds per square inch (psi) was available until November 22, when a booster station and a 100,000-gal reservoir tank were installed.

Aggregate for the concrete used in the construction of T Plant was supplied from the Haven Barrow Pit, located approximately 0.5 miles west of the $100 \mathrm{~B}$ Area; from the Hanford Barrow Pit, located about 1 mile west of the old Hanford townsite; from a barrow pit dug in the 200 West Area on the site of the future 288-W Ash Disposal Basin, near the east-center of the 200 West Area; and from the excavations for the 221-T and 221-U Buildings themselves. Aggregate from the Haven and Hanford pits was brought to the 200 West Area on temporary, standard-gauge rail tracks that terminated at the 200-T Building, a temporary batch plant for the mixing and pouring of concrete used in the construction of 221-T. This batch plant, which stood near T Plant, was disassembled and moved to the 200 East Area after $90 \%$ of the concrete had been poured for T Plant in early June, 1944. The remainder of the concrete for $T$ $\mathrm{Pl}$ ant was supplied from the nearby 200-U Batch Plant. Additionally, a special yard was constructed in the 200 West Area for the fabrication of precast concrete cell block covers.

The original construction schedule for $\mathrm{T} P \mathrm{Pl}$ ant, established by the prime HEW contractor, the E. I. duPont de Nemours Corporation (duPont) of Wilmington, Delaware, placed completion at "30 days after the completion of 100-B" Area.' Early construction progressed very slowly, because of a shortage of manpower. During the first six months of construction (June through December 1943), only $3 \%$ of the work was completed. This portion of the work mainly consisted of excavation work for the canyon and the erection of temporary construction support structures and facilities. In September, a two-month "hold" was placed on permanent construction in the 200 West Area, to free workers to build additional living quarters in the Hanford Construction Camp. (By 1944, this camp, located at the old Hanford townsite, housed 51,000 people.) During this two-month period, less than 300 workers were available to work on the entire 200 West Area!

Normal work forces returned to 200 West Area construction on November 28, 1943. The 75-ton overhead crane, which was to be used to transfer irradiated slugs from their railroad well-cars to the dissolvers in Sections 3 and 4 of T Plant, was installed early, so that it could be used in construction operations. In December, a special 65-ft-long "Head End Addition," to house laboratory equipment for radiochemical process improvement tests for the bismuth phosphate separations process used at HEW, was authorized for 
T Plant. ${ }^{2}$ The design of this test laboratory section corresponded to two standard sections of T Plant, except that it contained smaller-capacity equipment (Section 4.0).

In March 1944, the duPont Corporation ordered a sharp increase in the work forces dedicated to the 200 West Area. Such forces peaked in May 1944 at 4,960 workers. Employment in the 200 West Area remained at $90 \%$ of this peak through July 1944 and declined gradually after that as more skilled crafts were required for equipment and instrument installations in T Plant and other structures. From July 5 through August 25, 1944, all skilled pipefitters and welders were diverted from work on U Plant, B Plant, and other structures and dedicated to completion of key portions of B Reactor and T Plant.

Beginning in early September 1944, portions of the T Plant building and equipment were completed and turned over to the Operating Department. Equipment calibrations and "water runs," or tests with water instead of process solutions, were started gradually, and some last-minute design changes were made as a result of these trials. The largest single modification was a complete regasketing of $T$ Canyon equipment, when it was found that the original plastic gaskets allowed leakage under impact with the remotely controlled flanges. Additionally, the equipment testing phase revealed that the brass ends of the neoprene flexible connectors in the hydraulic system piping of the centrifuges cracked under strain. Steel-ended flexible connectors were procured and installed.

At midnight on 0ctober 8, a 11 construction forces, including standby men, were removed from $T$ Plant. Chemical runs, and then practice runs using cold (unirradiated) slugs having defective aluminum jackets (covers), were made during November and early December. Flushing and calibration tests were essentially complete hy November 20, and Operating Department personnel began preparations for a preliminary startup. Actual runs using process solutions began on December 6 , and the first batch of irradiated fuel rods from B Reactor was processed on December 26 and 27, 1944. 


\subsection{PERSONNEL AND - TRAINING}

The first group of $T \mathrm{Pl}$ ant operations personnel to be hired consisted of 60 men transferred in the autumn of 1944 from the 300 Area fuel manufacturing sector of the "P" (Production) Department, the organization responsible for fuel fabrication and irradiation activities. A second group of 150 men was chosen in early 1945, from interviews with approximately 400 people from both onsite and offsite, who were seeking work as war construction jobs decreased. During late 1944, a training program for $T$ Plant operators was prepared by a senior supervisor. This program initiated general and job-specific training courses for each operator, demanded familiarity with a new "S" (Separations) Department training manual, and provided that the operators complete a required list of sitewide training classes in safety, security, transportation, company policies and regulations, and other subjects. According to dupont Corporation records, the "primary task was to familiarize them [plant operators] with the operating equipment and processes required for the proper execution of assigned jobs, and to provide them with actual practice necessary to develop proper technique in operating the equipment. "3 Shift supervisors were made responsible for training the men assigned to them.

When training $\mathrm{classes}$ had been completed, operators were allowed to assist in water runs and then chemical runs through the plant. Only after completing those practice runs were they allowed to participate in processing active uranium. In February 1945, those individuals in the first group of 60 men who demonstrated the necessary qualifications were advanced from "B" to "A" class operators. Half of the original group then was transferred to $B$ Plant to lead the equipment flushings and instrument calibrations for that facility. 
WHC-MR-0452, ADDENDUM 1

This page intentionally left blank. 


\subsection{CELL STRUCTURE AND USAGE}

T Plant contained 42 concrete process cells, arranged in 20 pairs (called sections) along the length of the building. Originally, in June 1943, the plant was designed to have 38 cells. However, later that year, according to duPont, experimental developments in the extremely new and emerging chemical separations process to be carried out in the facility "necessitated the inclusion of an oxidation by-product precipitation ahead of the extraction of the product from the metal solution. This required the use of two cells, so in order to retain the desirable feature of a spare cell near the middle of the building, the oxidation step was assigned to Celis 11 and 12 and all subsequent steps in the process were moved down two cell numbers to compensate.

Still later that year, a special $65-\mathrm{ft}$ addition, consisting of "two double-size equipment cells and contir'lations of the three galleries and crane rails," was authorized for the building. The addition was deemed necessary by the duPont Corporation, in order to have a "hot semi-works laboratory...to study and evaluate the various steps in the process and for process troubleshooting'."5 The criteria for this semiworks (pilot-scale process testing facility) were that it be able to handle small-scale batches of full-strength plant solutions and irradiated metal, that it not interfere with the normal operation of $\mathrm{TPl}$ Pat, and that it allow access to and cleaning of test equipment so thoroughly that manual inspection and changeouts would be feasible. As finaliy constructed and equipped, the semiworks was separated from the main portion of $\mathrm{T} P \mathrm{Plant}$ by a thick concrete barrier wall, and it contained 14 process vessels, each scaled down to $5 \%$ the size of the main plant equipment.

Within the main body of T Plant, each standard section was $40 \mathrm{ft}$ long, and each individual cell was approximately $13 \mathrm{ft}$ by $17 \mathrm{ft}, 8 \mathrm{in}$. by $22 \mathrm{ft}$ high, with 7-ft-thick concrete walls and 6-ft-thick cover blocks. One exception to this size limitation was Cell 3, which was designed to provide a 23-ft cell with adequate shielding to house the railroad tunnel into the building. The other exception was Cell 5R (Right), the collection area for miscellaneous in-plant process wastes, which was built with an additional $20 \mathrm{ft}$ of depth belowgrade.

The cover blocks of each cell in T Plant consisted of removable sections with stepped, interlocked edges to prevent the escape of radiation. Twelve of the 20 sections in T Plant each contained a standard grouping of process equipment that consisted of four pieces: a precipitator, a catch tank, a centrifuge, and a solution tank. (These were Sections $6,7,8,9,10,13,14$, $15,16,17,18$, and 19.) All pipe, instrument, sampling, and control lines into the cells were buried in the concrete and terminated in standardized connector flanges on the cell walls. Each of the electrical lines contained six leads. The other instrument, hydraulic, and lubrication lines contained four small pipes. The chemical feed, steam, and water lines consisted of single, 2- or 3-in. pipe. To minimize the escape of radiation into the pipe gallery, an S-curve was built into the piping as it ran from the cells to the gallery. Within each section of $\mathrm{T} P \mathrm{Plant}$, process lines between cells were run 
directly through cell walls. However, because of "difficulties created by the expansion joint which separates adjacent sections," no piping pierced the walls between sections. ${ }^{6}$

According to the duPont builders of T Plant, "flexibility" and the need for remote maintenance were the governing factors in the design of the facility: "At the time design was begun, the [separations] process was largely undeveloped. This required the incorporation of sufficient flexibility to permit minor changes and also fundamental alterations in the equipment arrangement and process flow. To accomplish this, the Cell Building was designed, as far as possible, as a group of standard units in which different types of process vessels, pipe connections, and instrument connections can be installed without requiring structural modifications." 7

The original uses and designations for the $T$ Plant sections and cells are as follows.

Head-End Addition (Cells A and B): Originally used as the radiochemical process improvement semiworks for the Hanford Engineer Works. For other subsequent uses, see Section 9.0.

Section 1 (Cells 1 and 2): Storage of contaminated, discarded equipment.

Section 2 (Cell 3): Railroad tunnel for bringing in irradiated metal.

Section 2 (Cell 4): Storage of slugs with ruptured jackets. (NOTE: This cell was kept filled with water.)

Section 3 (Cells 5 and 6 ): Coating removal and metal dissolving and reduction.

Section 4 (Cell 7): Coating removal and metal dissolving and reduction.

Section 4 (Cell 8): Metal solution storage.

Section 5 (Cell 9): Sewage disposal and holding tanks.

Section 5 (Cell 10): Sewage disposal and sewer cell.

Section 6 (Cells 11 and 12): Spare. Sometimes was used for a by-product precipitation before extraction.

Section 7 (Cells 13 and 14): Extraction (spare).

Section 8 (Cells 15 and 16): Extraction.

Section 9 (Cells 17 and 18): Treatment of waste metal soiution.

Section 10 (Cells 19 and 20): Treatment of waste metal solution (spare).

Section 11 (Cells 21 and 22): Spare (unequipped as of 1945).

Section 12 (Cells 23 and 24): Storage and oxidation of metal solution. 
WHC-MR-0452, ADDENDUM 1

Section 13 (Cells 25 and 26): First decontamination cycle, by-product precipitation.

Section 14 (Cells 27 and 28): First decontamination cycle, product precipitation.

Section 15 (Cells 29 and 30): Treatment of decontamination wastes.

Section 16 (Cells 31 and 32): Second decontamination cycle, by-product precipitation.

Section 17 (Cells 33 and 34): Second decontamination cycle, product precipitation.

Section 18 (Cells 35 and 36): Third decontamination cycle (spare).

Section 19 (Cells 37 and 38): Third decontamination cycle (spare).

Section 20 (Cells 39 and 40): Spare (unequipped as of 1945). 
WHC-MR-0452, ADDENDUM 1

This page intentionally left blank. 


\subsection{ORIGINAL SEPARATIONS PROCESS}

The original separations process used at HEW was the bismuth phosphate $\left(\mathrm{BiPO}_{4}\right)$ process. The steps of this process were carried out first in $\mathrm{T} P \mathrm{Plant}$, then in the 224-T Bulk Reduction Building, and then in the 231-Z Isolation Building. The entire operation was a batch precipitation process that achieved separation by varying the valence state of ${ }^{239} \mathrm{Pu}$, and then by repeatedly dissolving and centrifuging plutonium-bearing solutions. It was based on the principle that bismuth phosphate is similar in crystal structure to plutonium phosphate. By precipitating bismuth phosphate, the ${ }^{239} \mathrm{Pu}$ in the +4 (tetravalent) state could be carried with it. In the +6 (hexavalent) state, the ${ }^{239} \mathrm{Pu}$ would not carry with the bismuth phosphate, and a by-product precipitation could be achieved. The plutonium was reduced (taken to the tetravalent state) by adding oxalic acid or ferrous ions and oxidized (taken to the hexavalent state) by adding sodium bismuthate (when bismuth phosphate was the carrier), or potassium permanganate (when lanthanum fluoride was the carrier). Actually, lanthanum fluoride was known to be a better carrier of plutonium, in that it could carry with a smaller bulk or volume and could carry away the stronger lanthanides such as cesium, strontium, and lanthanum. However, it is very corrosive; and for that reason, it was rejected for the main phase of the Hanford separations process.

The first step in the separations process carried out in T Plant was dissolving, a process that removed the aluminum fuel jackets from the uranium elements. It was carried out in the dissolvers and metal solution storage tanks located in Sections 3 and 4 ( Cells 5, 6, and 7) of the canyon. The irradiated, jacketed fuel rods first were placed in boiling sodium hydroxide, to which sodium nitrate slowly was added (to reduce the formation of hydrogen). This step produced "coating removal waste." Next, 3 metric tons of declad metal were charged into a dissolver. Nitric acid was added in three increments, enough to dissolve 1 ton in each increment. To keep the time cycle as short as possible, "a substantial metal heel" was left in the dissolver between charges. New material was charged on top of this heel. In June 1945, a second dissolver was placed into operation in T Plant.

The second step in the process was the extraction step. This operation separated the product $\left({ }^{239} \mathrm{Pu}\right)$ from most of the uranium. It also removed about $90 \%$ of the fission products into what was called the metal waste solution. The extraction step reduced the gamma radiation activity level by a factor of 10. In the first extraction step, plutonium was kept in the +4 (reduced) valence state. Bismuth nitrate and phosphoric acid were added to the solution that contained the dissolved fuel elements, causing the formation of bismuth phosphate. A product precipitation (one that carried the plutonium with it) then occurred. The precipitate was centrifuged to separate the solid portion from the liquid. The liquid portion was jetted away as waste. The solid portion ("precipitate cake"), which contained the plutonium, was placed in another tank and dissolved with nitric acid. Sodium bismuthate or potassium permanganate were added to the plutonium-bearing solution to oxidize the plutonium to the +6 state, and then sodium dichromate was added as a holding agent to keep the plutonium steadily fixed in this state. The $\mathrm{BiPO}_{4}$ then precipitated as a by-product, leaving the plutonium in solution. 
The third step, decontamination, essentially was a repetition of the extraction process. The final decontamination cycle reduced the gamma ray activity level by a factor of 10,000 , giving an overall process "decontamination factor" of 100,000 below that of the original uranium solution. The plutonium-bearing solution from the extraction step was reduced with the addition of ferrous ammonium sulfate. Then, bismuth nitrate and phosphoric acid again were added, a product precipitation occurred, and the precipitate was centrifuged. The solid portion, containing the plutonium, was liquified with nitric acid, oxidized, and the remaining $\mathrm{BiPO}_{4}$ precipitated away as waste.

Plutonium-bearing solution was transferred from the southwest end of $T$ Plant to the 224-T Building via underground piping. The starting batch size in the latter facility was 330 gal. Here, the plutonium solution from the 221 Buildings was oxidized with sodium bismuthate. Phosphoric acid then was added to produce a by-product precipitation, leaving the plutonium in solution. Centrifuging then separated the solution and precipitate. Nitric acid was added to dissolve the by-product cake, and it became waste. Next, the plutonium-bearing solution was oxidized with potassium permanganate $\left(\mathrm{KMnO}_{4}\right)$. Hydrogen fluoride and lanthanum salts were added, in what was known as the "crossover" step. A lanthanum fluoride precipitate was produced, leaving hexavalent plutonium in solution.

Impurities were precipitated in a by-product cake, as the fission products were carried with the lanthanum. This by-product cake contained all of the lanthanides (e.g., cerium, strontium, and lanthanum) that the $\mathrm{BiPO}_{4}$ could not carry out of the stream. The cake was dissolved in nitric acid, neutralized with sodium hydroxide, and sent to tanks for settling. The plutonium solution then was reduced to +4 state by adding oxalic acid. Lanthanum salts and hydrogen fluoride again were added, thus precipitating lanthanum fluoride that contained the plutonium. The precipitate was separated by centrifugation, and potassium hydroxide was added to metathesize the plutonium lanthanum fluoride, forming a solid plutonium lanthanum oxide. (Metathesis is a chemical process to convert a solid to another solid.) Any liquid was removed by centrifugation, and the solid plutonium lanthanum oxide was then dissolved in nitric acid to form plutonium nitrate. By this time, the original 330-gal batch that had entered the 224-T Building had been concentrated to $8 \mathrm{gal}$ (volume).

Lastly, the plutonium nitrate from this facility was sent to the 231-Z Building for the final processing that could be done at the HEW. Hydrogen peroxide, sulfates, and ammonium nitrate were added to the plutoniumbearing solution. The hexavalent plutonium precipitated as plutonium peroxide. Nitric acid then was added to dissolve this precipitate. The plutonium nitrate then was placed in small shipping cans and boiled right in these cans, using hot air. It was reduced to a wet nitrate paste. In this form, the plutonium was stored in the $213-J$ and $K$ Vaults in the southeast end of Gable Mountain, and then shipped to the secret Los Alamos Site. Each shipping can held about $1 \mathrm{~kg}$ of plutonium. ${ }^{8}$ 


\subsection{SUPPORT AND ANCILLARY STRUCTURES ASSOCIATED WITH THE T PROCESS GROUP}

Aside from the most central buildings of the $T$ Process Group (the 221-T and 224-T Buildings), and the 231-Z Building, many other facilities were built during World War II to support T Plant. Among these were the following.

\section{1-T Tank Farms}

The 211-T Tank Farm functioned to store and supply fresh chemicals to $T$ Plant. It was located aboveground, at the rear of 221-T Building, in the angle between the 271-T Building and the railroad tunnel that entered $T$ Plant to deliver irradiated fuel rods ready for processing. The 211-T Tank Farm consisted of nine vertical, stainless steel storage tanks that held acids (five for $60 \%$ nitric acid, three for $75 \%$ phosphoric acid, and one for $90 \%$ formic acid). Six horizontal, stainless steel tanks held the full-strength, concentrated nitric acid that was received in rail shipments, as well as the facilities to dilute this acid to the $60 \%$ strength that actually was used at the plant. Three additional steel tanks held $50 \%$ caustic solution (sodium hydroxide), one steel tank held sulfuric acid, another tank on scales held anhydrous hydrofluoric acid, and a small expansion tank was provided as a spare, to provide for overfiow and prevent the rupture of other tanks. Transfer and circulation pumps, as well as drum-filling facilities, completed the 211-T Tank Farm.

\section{2-T Sample Preparation Laboratory}

(a) so known as the Control Laboratory)

The 222-T Laboratory functioned to test the 221-T and 224-T process solutions at various stages in the processes, to determine the product concentration and the rate of product decontamination. Because the entire separations process was conducted remotely, verification that the process was working correctly could be obtained only by drawing samples and conducting radioassay. Product concentration was measured by the alpha ray disintegration rate, and product decontamination (i.e., separation from unwanted fission products) was measured by beta and gamma ray disintegration rates.

The laboratory building was located between the 224-T and the 292-T Buildings. It contained 22 rooms, including chemical and sample preparation laboratories; the sample measurement (counting) room; balance room; instrument repair room; equipment and machinery rooms; receiving room; and others. The counting room in this structure was shielded by $2 \mathrm{ft}$ of concrete. Samples were removed from T Plant via riser pipes that led into small, lead-shielded sampler pits located approximately $2 \mathrm{ft}$ below the canyon deck level in the cell walls. A long, thin "trombone" apparatus was inserted into the riser pipe to withdraw a sample, which then was transferred into a stainless steel "door-stop" carrier. Less active samples (or those predicted to be less active) were transported to the laboratory in "bayonet" pipette carriers. In the 222-T Building, active samples then were stored on shelves behind an additional 1 in. of lead shielding. In late 1950, additional shielding and ventilation equipment was added to reduce radioactivity levels 
around the waste sample disposal and equipment decontamination bench in the building. Further upgrades to the building added new acid dispensing equipment and piping in 1951.

\section{4-T Bulk Reduction Building}

The operations of the 224-T Bulk Reduction Building previously have been described in terms of the bismuth phosphate process. This three-story building contained 21 rooms and five reinforced concrete cells, with the large Operating Gallery located on the third floor. In 1950, equipment in $F$ Cell was rearranged to allow parallel operation of two centrifuges, thus boosting production. In 1955, when plans were being formulated for the shutdown of $T$ Plant, consideration was given to installing the 231-W Isolation Building process in the 224-T Building. However, this change did not take place. In 1975, the 224-T Building was modified to become a storage facility for plutonium-bearing scrap and liquids. In 1985, it became known as the Transuranic Storage and Assay Facility (TRUSAF) Building and began storing drums containing wastes contaminated with transuranic substances. 11

\section{1-T Process Waste Disposal Systems}

See Section 10.0 .

\section{1-T Chemical Preparation and Service Building}

The 271-T Building functioned to receive, store, mix and deliver the chemicals used in the bismuth-phosphate process into $T$ Plant. Attached to the back (northwest) wall of the 221-T Building at the midpoint (adjacent to Sections 10 through 13), the large 271-T Building also provided the supervisory office space for T Plant. The basement and first floors contained chemical storage facilities, instrument and maintenance shops, ventilating equipment, and change rooms. The second floor contained offices, while nearly the entire third floor housed a large chemical preparation room with a smaller chemical control laboratory to sample the chemical mixtures before they were delivered into $T$ Plant. Although this reagent control laboratory was deactivated in the late $1940 \mathrm{~s}$, it was refitted with new equipment during the production increases of the early 1950 s $_{\text {iz }}$ Two labyrinth accessways were provided into the $T$ Plant crane cabway. ${ }^{\text {i2 }}$

\section{1-T Exhauster Building and Stack}

The 291-T Stack functioned to exhaust process gases from the 221-T Building. Additionally, three fans (two electric for regular use and one steam for emergency backup) with blower equipment located in the small 291-T Exhauster Building at the base of the stack provided the additional "diluting air" deemed essential to the safe dispersion of process gases in the atmosphere. The stack itself was $200 \mathrm{ft}$ high and was located $252 \mathrm{ft}$ from the head-end face of the 221-T Building. It was connected to T Plant via underground inlet and outlet air ducts. The inlet duct was L-shaped, $4 \mathrm{ft}$ wide by $7 \mathrm{ft}$ high, with 12 in.-thick concrete walls. It ran at a right angle to the line of the fans in the 291-T Building and to the 221 Building and connected with the latter structure at the center of Section 3 (between Cells 5 and 6 ). This connection point was chosen because the dissolver 
offgases, located in the first Sections of $T$ Plant, were the emissions of concern to HEW officials. This last section of the inlet duct paralleled the outlet duct and was separated from it by a concrete wall. The operation of the fans jn the 291-T Building was sufficient to add an average of $20,000 \mathrm{ft}^{3} /$ minute to the process gasses exiting $T$ Plant during normal, World War II dissolving operations. Further discussion of the action of the 291-T Facilities can be found in Section 11.0.

\section{2-T Exhaust Gas Laboratory}

The 292-T Exhaust Gas Laboratory functioned to sample and test the 291-T Stack gases for levels of chemical and radioactive contaminants. This small ( $336 \mathrm{ft}^{2}$ ) building was located approximately $40 \mathrm{ft}$ from the centerline of the 291-T Stack, in the direction of the 222-T Sample Laboratory. The decision to add this building to support the $T$ Process Group was made in the spring of 1944, when dupont health physicists proposed that: "The 291 control house is not a suitable place for this [monitoring] equipment because of cramped quarters and possible interference from steam engine vibration. A separate building near the stack is recommended." The 292-T Building contained no windows but had roof ventilators and gas refrigeration and testing equipment. It was connected to the $291-T$ Stack via a 2 -in. overhead sampling line. The gases were drawn into the 292-T Building and passed through a small water scrubber (containing $5 \%$ soda ash solution), dried via refrigeration, and then counted in a chamber to measure the ${ }^{133} \mathrm{Xe}$ activity. The scrubbing, water then was counted in a sep rate apparatus to determine the ${ }^{131}$ I activity. ${ }^{14}$ Further discussion of the 292-T Facility can be found in Section 11.0 .

Several other buildings and facilities were constructed to support the entire 200 West Area. As such, they functioned in support of T Plant. The following is a brief listing of these facilities:

252-W Secondary Substation

253-W Distribution Substations (21)

272-W Area Shop

274-W Machinery Storehouse

275-W Chemical Storehouse

282-W Reservoir and Pump House

283-W Filter Plant Building

284-W Power House

288-W Ash Disposal Basin

2701-W Gate House and Clock Alley

2704-W Supervisor's Office Building

2707-W Change House

2709-W Fire Headquarters

2713-W Storeroom Building

2713-WA Essential Materials Storehouse

2713-WB Miscellaneous Storehouse

2715-W $0 i 1$ and Paint Storage Building

2716-W Automotive Repair Garage

2719-W First Aid Building

2720-W Patrol Headquarters

2722-W Paint and Riggers' Shop

2729-W Extra Machinery Storehouse 
WHC-MR-0452, ADDENDUM 1

2730-W Salvage Yard

2731-W Burning Pit

2734-W Cylinder Storage Building

2501-W Fence and Road Lights

2503-W Transmission Lines

2505-W Fire Alarms

2506-W Telephones and (Telephone) Cables

2601-W Railroad Tracks

2603-W Roads and Walks

2605-W Fences and (16) Guard Towers

2607-W Underground Septic Tanks

2612-W Open Drainage Ditches

2613-W Parking Lots

2614-W Monitoring Stations (6)

2621-W Emergency Gasol ine lienerator Buildings

2801-W Outside Overhead Pipe Supports

2802-W Outside Overhead Steam Lines

2803-W Outside Overhead Air Lines

2805-W Outside Overhead Process Lines

2901-W Outside Underground Water Lines

2902-W Outside Underground Fire Lines

2903-W Outside Underground Sanitary Sewers

2904-W Outside Underground Process Sewers. 


\subsection{EARLY OPERATING EXPERIENCE}

Operating experiences during the first few months of $T$ Plant's operations were described by duPont as "unusually satisfactory." 15 No serious mechanical problems developed, except that the bowl of the centrifuge in Section 16 jammed against some dip tubes when it was run backwards on January 5, 1945. The centrifuge was replaced via remote operations, partially decontaminated in a spare cell, and then buried in 1954 when it was determined that it could not be repaired. This and other miscellaneous remote tasks gave operators confidence that "the Canyon Buildings can be operated remotely as planned and with somewhat less loss of fabricated equipment than originally anticipated." 16

During the next six months of $\mathrm{T} P \mathrm{Plant}$ operations, procedures were standardized. Technical efforts were directed toward reducing time cycles, as production sped for the special nuclear materials needed to win the war. By mid-1945, emphasis had shifted to "a review of process technology and operating technique in an effort to improve efficiency and reduce waste losses." 7 Free nitric acid concentration was reduced to obtain an increase in the specific gravity of dissolver solutions. The most significant improvement, however, came in the late summer, with the installation of piping to allow for intermediate solution transfer from storage to the precipitator in Section 6 (Cells 11 and 12). This was a safety measure, as metal solution slightly in excess of charge requirements then could be taken from storage, agitated, and sampled so that the correct amount, based on critical mass limitations, could be transferred to the extraction sections of the plant. Further safety improvements included more rigorous efforts to empty and decontaminate the precipitators used in the extraction and decontamination cycles. These measures ensured the prevention of ${ }^{239} \mathrm{Pu}$ buildup on equipment.

During 1946, much experimentation was done in T Plant to lower further the quantities of phosphoric acid required in the product precipitation steps of extraction and decontamination. Reductions in the molarity of this acid, as well as in sodium hydroxide and calcium carbonate were achieved

successfully. Additionally, the "problem of batch size control and prevention of product accumulation received attention throughout the period." 18 "New connector assemblies were installed to bypass certain process vessels where the headroom was insufficient to allow for in-tank agitation and where, consequently, product-bearing precipitates might settle. Acid washings of catch tanks in the precipitation cells also were increased, to prevent ${ }^{239} \mathrm{Pu}$ accumulation, and sampling of standpipes and other transfer lines was increased. As a result of the vigorous acid washes, higher than normal material balances occurred at $T$ Plant during the summer.

At the same time, according to dupont, the "process equipment began to show the effects of one and one-half years of operation. "19 "The failure of centrifuges, skimmers, and dip tubes accounted for "a fair portion of the maintenance load." 20 "Transfer jets gave "regular though minor troubles," and asbestos gasket failures became common. Piping lines began to fail because of corrosion and/or metal fatigue, and piping jacket leaks increased. However, the 75-ton remotely handled crane "gave performance bordering on perfection." 21 
WHC-MR-0452, ADDENDUM 1

This page intentionally left blank. 


\subsection{EARLY PROCESS CHANGES}

T Plant and the other Hanford separations canyons were designed on the basis that one plant would have the capacity to process the output from one pile (reactor). With each HEW reactor originally planned to produce 1 metric ton of metal (containing approximately $250 \mathrm{~g}$ of product [ $\left.{ }^{239} \mathrm{Pu}\right]$ ) each day, the earliest standard procedure for T Plant involved starting a 1-metric-ton charge of metal into the dissolvers about every 26 hours. However, by the summer of 1945, production tests had shown that charge size could safely be increased to 1.5 metric tons of metal., "without noticeable effect of yield or equipment performance." 22 By September 1, process modifications enabled the plant to complete the processing of a charge in just 20 hours, with only a $10 \%$ allowance added onto the average process cycle for equipment repairs.

Other very early changes included the elimination of potassium carbonate from the separations process in February 1945, and one month later, because of the unavailability of potassium hydroxide containing only $0.0005 \%$ iron impurity, the relaxation of process specifications for this chemical to allow for $0.005 \%$ iron impurity. Overall, the first full-scale separations experiences at $T$ Plant and at the 224-B Bulk Reduction Building and the 231-Z Isolation Building, led to large reductions in many essential materials, per unit of production. For example, the strength of the key dissolving agent. nitric acid was decreased from an average of $95 \%$ to an average of $69 \%$ (a $33 \%$ reduction). By September 1, 1945, other chemical requirements were reduced as follows (per unit of production):

Phosphoric Acid...........28\%

Sulfuric Acid..............

Hydrofluoric Acid..........58\%

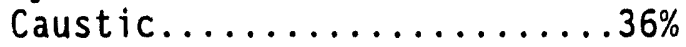

Soda Ash..................14\%

Ammonia Silicofluoride.......42\%

Bismuth Subnitrate..........40\%

Ferrous Ammonium Sulfate....66\%

Hydrogen Peroxide...........33\%

Potassium Permanganate.......55\%

Potassium Hydroxide..........34\%

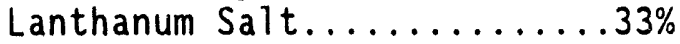

Sodium Nitrate.............28\%

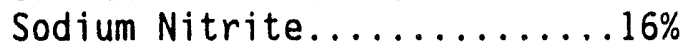

Oxalic Acid................56\%

Sodium Dichromate.........62\%

Sodium Bismuthate..........56\%

Zirconium Carbonate Gel.....66\%

Potassium Carbonate.........100\% (eliminated from the process). 
Additional and ongoing process improvement studies carried out during the 1945 to 1946 period were directed at the following activities: simplification of operations to achieve reductions in process time, modification of the process to increase canyon capacity per batch, reduction in waste volumes, recovery of additional product from wastes, the establishment of better understandings of process safety and safety limits, decontamination improvement, and basic studies in the chemistry of plutonium. Such studies were pursued in the T Plant semiworks (Cells $A$ and $B$ ), in the 3706 Radiochemistry Building, and in the 321 Separations Building. 


\subsection{SEMIWORKS MISSIONS}

The radiochemical process improvement semiworks in the head-end addition of T Plant was completed in September 1944. Chemical and tracer runs were undertaken through December 1944, when full-strength experiments were undertaken in the extraction and first-cycle decontamination steps of the bismuth phosphate process. A four-step decontamination process, consisting of washes with nitric acid, ammonium silicofluoride, and hydrogen peroxide then was undertaken. A Cell was decontaminated sufficiently to permit entry, but B Cell could not be brought to acceptable contamination levels. On January 13,1945 , the semiworks was placed on cold standby, and all personnel were transferred to the 321 Separations Buildings, designated for "cold" process improvement runs. On February 12, it was necessary to reactivate the hot semiworks in T Plant, to conduct tests in which scavengers were omitted from the by-product step and ammonium silicofluoride was used in the product step. Another test was conducted in which the extraction cake was washed with potassium hydroxide. Following these tests, the facility again was decontaminated, and, in March, process improvement trials and personnel were transferred to the 321 Building.

The T Plant semiworks facility continued to run on an intermittent but infrequent basis, making research and development trials for the bismuth phosphate process through early 1947. At that time, the newly formed U.S. Atomic Energy Commission (AEC) directed Hanford Works (HW), the new Site designation under the $A E C$, to begin immediate and rapid development of a continuous solvent extraction chemical separations process. Because the equipment in the head-end addition of $T$ Plant was not suited to such a process, the semiworks was decontaminated and closed. In early 1949, the original equipment was removed to prepare the space for use as a separations facility for radioactive lanthanum $\left({ }^{140}\right.$ La), known as "RALA," a tracer gas ordered by the Air Force for tracking nonnuclear explosions. Made from irradiated barium, RALA had a half-life of only 40 hours: so quick that small-scale separation was necessary. Design studies for modifications to Cells $A, B$, and 5 in T Plant, as well as modifications to the offgas scrubbers that by then had been emplaced for the 291-T Stack, were completed in the spring of 1950. The construction of some temporary facilities, such as hoists, hand rails, access platforms, and fencing also was completed. However, before the major modifications could be emplaced, the AEC decided to place the RALA program with the newly authorized National Reactor Testing Station (now Idaho National Engineering Laboratory), to be built near Idaho Falls, Idaho. ${ }^{24}$ 
WHC-MR-0452, ADDENDUM 1

This page intentionally left blank. 


\subsection{WASTE MANAGEMENT}

The earliest practices for handling bismuth phosphate wastes were based around the 241-T Process Waste Disposal Systems. This system consisted of 16 underground, single-shell tanks (SSTs) for the storage of high-level wastes; a gunite catch tank (or "sump" tank); a settling tank; four reinforced concrete diversion boxes; two retention basins; and eight observation wells. The high-level waste storage tanks were constructed of reinforced concrete with a $0.25-i n$. welded steel plate lining. Twelve of these tanks were $75 \mathrm{ft}$ each in diameter and were numbered in series from 241-T-101 to 241-T-112. Four of the high-level waste tanks were only $20 \mathrm{ft}$ each in diameter and were designated with numbers from 241-T-201 to 241-T-204. Additionally, a 20-ft-diameter catch tank, numbered 241-T-301, was located underground approximately $112 \mathrm{ft}$ away from Tank 241-T-112. Another 20-ft-diameter settling tank, numbered 241-T-361, al so was located underground to hold the process wastes from the 224-T Building on a short-term basis. After a settling period, the contents of this tank (except for an accumulated sludge or heel) were discharged into a pipe that carried used process cooling water.

Together, these two liquid streams were discharged into one of the two 500,000-gal retention basins. These basins, numbered 241-T-352 and 241-T-353, then overflowed into open, earthen drainage ditches that ran far out into the desert to the northwest of the basins. Additionally, four underground diversion boxes containing piping, pipe connectors, and water spray nozzles were a part of the process waste disposal system. They functioned to direct the flow of process wastes to the various tanks. Seven of the observation wells were $150 \mathrm{ft}$ deep, and one was $300 \mathrm{ft}$ deep. 25

The earliest HEW policies divided T Plant wastes into four types: coating removal waste (that generated in Cells 5 through 7 , specifically produced by the dissolving of the aluminum fuel coatings); first decontamination cycle waste (that containing approximately $90 \%$ of the fission products and virtually all of the uranium that did not convert to plutonium); second decontamination cycle waste (that containing approximately $10 \%$ of the fission products); and cell drainage waste (that collected from floor drains in the dissolver Cells 5 and 6 ). The first three types of wastes all were neutralized with sodium hydroxide and placed in the underground SSTs for storage in perpetuity (or until another final disposal alternative was developed). The cell drainage waste was settled, with the supernate then discharged to the ground.

As production increased at $T$ Plant in response to Cold War imperatives, tank space became scarce and the TX Tank Farm (18 SSTs, holding 750,000 gal each) was constructed during 1947 and 1948. At that time, "cribs" (also known as earth reservoirs) were first constructed to drain additional low-level wastes through covered void spaces and into the subsoil. The TY Tank Farm, containing six SSTs of similar capacity to the TX tanks, was built during 1951 and 1952. The first two waste evaporators at the Hanford Site, 242-T and 242-B, also started up in 1951 in an effort to conserve tank space. First cycle bismuth phosphate wastes were sent to these facilities for concentration by steam heat, with the condensate discharged to the ground and the concentrated high-level wastes sent to SSTs. 
At the same time, other efforts to optimize tank space, for only the highest level wastes, resulted in the decision to combine coating removal waste and second-cycle decontamination waste with cell drainage waste and 224 Building waste and to send all of this mixture to holding tanks. After settling, the supernate from this waste was discharged to cribs.

Additionally, older second-cycle wastes were taken out of SSTs and so discharged.

In some cases in the early 1950s, waste disposal tests resulted in the discharge of mid- and high-level wastes to the soil. In 1953 and 1954, supernatant from some of the older first-cycle wastes from $T$ and $B$ Plants were discharged to the ground through "specific retention" trenches. Specific retention practices were based on the theory that liquid waste would be "held against the force of gravity by the molecular attraction between soil particles and the surface tension of water." However, by 1957, the practice had been shown to work poorly, at least with Hanford soils and wastes, and its use was recommended at the Site only in "emergency" situations. In one trial campaign each in 1954, the bottoms of the 242-T and 242-B Evaporators, containing concentrated high-level wastes, were discharged to the ground. Additionally, in a 1955 and 1956 test, newly generated, first-cycle T Plant wastes were settled with chemical additives, and the supernatant was discharged to the $216-T-26 \mathrm{crib}^{26}$

By the time $T$ Plant shut down as a processing facility in early 1956 , approximately $87,285 \mathrm{Ci}$ of beta emitters and 7,840.83 $\mathrm{g}$ of plutonium had been discharged in liquid wastes sent to the ground in the various $T$ Plant trenches, cribs, swamps, and reverse wells. ${ }^{27}$ Unknown amounts of radionuclides had been disposed to the T, TX, and TY Tank Farms. 
WHC-MR-0452, ADDENDUM 1

\subsection{ATMOSPHERIC RELEASES AND HAZARD CONTROL}

As early as the first MED experiments with processes that would separate plutonium from irradiated uranium, it was known that all of the key processes generated highly toxic fumes in the metal dissolving phase. In fact, this knowledge contributed to the selection of the remote, eastern Washington site for the Hanford Engineer Works. Discussions between MED scientists and Army officials in August and October 1942 emphasized the intensely radioactive gases that evolved from metal dissolving along with the need for an isolated site. Similar discussions were held with the dupont Corporation in the autumn of 1943, at the time that it agreed to accept the contract to build and operate the nation's first plutonium production plants. dupont's top officials, like the MED scientists, urged the selection of a site far removed from centers of population. General Groves, in his memoirs, underscored the role of the metal dissolving gases in the selection of the Hanford Site: "We knew, too, that in the separation of plutonium we might release into the atmosphere radioactive and other highly toxic fumes that would constitute a distinct hazard."28 Further evidence of the generation of radioactive gases containing ${ }^{131}$ I and many other fission products from the bismuth phosphate separations process that would operate at HEW was found in the earliest operations of a separations pilot plant that was built at the Clinton Engineer Works (now the Oak Ridge Site). Known as the Clinton Semiworks (or the SMX), this plant began to operate in early 1944, with the same chemistry (albeit on a much smaller scale) that would be used at $T$ Plant. According to the duPont builders and operators of both the SMX and HEW: "The early experience at Clinton...sufficed to define rather clearly the radiation hazards to be expected in the separations process at Hanford." 29

The knowledge gained in the MED experiments and at the SMX prompted several early decisions at HEW. According to duPont, "these potentially serious conditions demanded that all such... by-products be disposed of safely. The means chosen consist of high [200-foot] ventilation stacks and fans which discharge the gaseous by-products to the atmosphere well above ground level." "Each cell within T Plant was connected to a main exhaust duct built into the concrete structure. A separate steam jet was installed for each dissolver, to propel the highly contaminated vapors from dissolver operations directly to the base of the stack. The stack itself was constructed of concrete on the outside, and "acid-resistant" mortar and brick on the inside. It extended from 714 to $914 \mathrm{ft}$ above sea level and was located at coordinates $N$ 43925, W 72935.31

Additionally, a temporary meteorological crew was brought to $\mathrm{HEW}$ as early as June 1943. Tasked with determining dominant wind patterns, velocities, and variances, the group soon found that the prevailing wind directions blew toward the northeast, east, and southeast. However, they also discovered complex micro patterns in wind directions and velocities over $\mathrm{HEW}$, including frequent and pronounced inversions. In early 1944, duPont's onsite construction chief, Gilbert Church, sought and obtained permanent status for the meteorology group at HEW. ${ }^{32}$ The group's work then expanded to include wind dispersion tests with oil fog $\left(\mathrm{SO}_{2}\right)$, begun in the partially completed $T$ Plant stack as early as April 1944. In the autumn of 1944, as construction and preoperations activities increased at $T$ Plant, these tests moved to the $C$ Plant stack and finally to the 400-ft HEW Meteorology Tower 
(622-R structure). The latter facility, located between and just north of the 200 East and 200 West Areas, was complete enough for use on December 7, 1944. An ancillary equipment facility and an observatory also were constructed to support the Meteorology Tower.

So extensive was the weather study and forecasting effort that by the end of 1944, over 36,000 individual readings on wind dilution patterns had been recorded in the 200 West Area. The meteorology group evolved some dominant theories. They described the offgas trajectories from the 200 East and West Area stacks in three possible conditions: "Fanning" denoted a wide, V-shaped path in which the gases followed the wind direction in a relatively straight line; "coning" described a narrow pattern, which al so followed a straight line downwind from the stack; and "looping" meant an undesirable condition in which the stack gases bounced from stack height to ground several times in their pathway down the wind stream. The former two cases occurred during "aloft conditions," defined by duPont as circumstances in which "process stack discharge [is/was] not expected to reach the ground." Looping, on the other hand, occurred during "unstable" air conditions, primarily inversions. It was seen as the worst-possible scenario, as the primary concern was to keep stack gases from coming to the ground close to the stacks where HEW workers could receive a concentrated dose. ${ }^{34}$

Because T Plant, as well as the other 200 East and West Area processing facilities at HEW, would operate without stack filters of any type, wind patterns and dilution factors, as well as the "cooling" (or aging) time that irradiated fuel rods spent between leaving the reactor and being chemically processed, became the chief means of control of the offgases. duPont scientists calculated the normal flow of air and process gases exiting the $T$ and $B$ Plant stacks to be $40,000 \mathrm{ft}^{3} /$ minute and then augmented this volume with an additional 20,000 $\mathrm{ft}^{3}$ /minute of "diluting air," giving a total stack flow of $60,000 \mathrm{ft}^{3} /$ minute. According to duPont, the "resultant $50 \mathrm{ft} / \mathrm{sec}$. velocity of discharge...assures considerable vertical 'carry' into the atmosphere and assists dispersion." At this stack flow rate, they continued, "dilution factors greater than 1000:1 are considered favorable, those from 500:1 to 1000:1 moderately satisfactory, and those less than 500:1 unfavorable." It became HEW policy to dissolve only when the "ground dilution expectancy" ratio of air to gases was 500:1 or greater. 35 To "schedule dissolver operations when atmospheric conditions are conducive to maximum dispersion," hourly and 12-hour "dissolving forecasts" were phoned to T Plant, beginning with the cold runs in November 1944. According to duPont, "these forecasts, along with more direct observations, allowed the start of each dissolving to be scheduled with reasonable success." After May 1945, believing that the hourly and 12-hour forecasts had proved "too short for effective scheduling of dissolver operations, " the meteorology team switched to a single, daily (24-hour) dissolving forecast. ${ }^{36}$

Scientists connected with the Manhattan project had realized since the earliest separations experiments that longer cooling times after irradiation a1lowed for greater decay of the chief airborne fission products of concern, ${ }^{131} \mathrm{I}$ and ${ }^{133} \mathrm{xe}$. Using the meteorological calculations for necessary wind dilution factors along with the addition of the fan-driven diluting air in the 
WHC-MR-0452, ADDENDUM 1

stack gases, HEW chemists decided in the autumn of 1944 that "If the normal wind dilution factor is $1000 \ldots$ lodine tolerance levels" in the vicinity would "not be exceeded" if the metal was cooled for 30 days."

With startup conditions thus defined, and the meteorological program in place, hot processing began at $T$ Plant on the night of December 26, 1944. The metal had been aged 32 days, and its activity was about 10 times as high as any that had been processed at the SMX. Somewhat surprised at the 1,700 $\mathrm{Ci}$ of ${ }^{13}$ I that was evolved, dupont reported that the "first significant plant discharge of radio xenon and radio lodine into the atmosphere at Hanford" had occurred. 38 Throughout the spring and early summer of 1945 , metal cooling times fell, as HEW rushed to produce the plutonium for the Trinity and Nagasaki bombs. Exactly how short the metal decay periods became is unknown, but $i t_{30}$ is known that they fell below 30 days and to perhaps as $10 \mathrm{w}$ as a few weeks. ${ }^{39}$ dupont operators reported "very little trouble with atmospheric contamination" until May 1945, when there was a sharp increase in metal activity, increased dissolving frequency, and the change to warmer spring weather. They noted that incidences of highest contamination occurred "during the middle of the day, when maximum outside temperature prevailed." Unstable inversion and lower wind velocities at those times led to a decision in early June to confine dissolving operations to the nights. ${ }^{40}$

At the end of World War II in August 1945, a large inventory of irradiated fuel rods from HEW's three production reactors, $B, D$ and $F$, awaited processing. The number of fuel charges being processed rose at $T$ and $B$ Plants from 22 in June 1945, to 77 in December. Beginning in September of that year, according to duPont, chemical processing was carried out in "uninterrupted operation." Further, "an effort was made to reduce the processing time cycle and to increase the amount of metal processed per charge." Between July and December, dissolving was carried out under "favorable" conditions only $60 \%$ of the time, and HEW's Health Instruments (H.I.) Section, a part of the Medical Division, reported "an increase in radioactive iodine deposits on vegetation in outlying districts." Concerned, HEW officials increased the metal cooling time from about 35 to about 60 days, beginning in December. During the period from January through August 1946, dissolving was carried out under "favorable" conditions $64 \%$ of the time. ${ }^{4}$

As a result of the dissolving practices and quantities of irradiated material processed through $T$ and $B$ Plants, at least $345,000 \mathrm{Ci}$ of 131 I was released to the atmosphere during 1945 , and 76,000 additional $\mathrm{Ci}$ ( $\left.{ }^{131} \mathrm{I}\right)$ were released during 1946. ${ }^{42}$ In the meanwhile, the learning curve cont inued concerning the deposition and buildup of airborne fission product activity in the HEW plant areas and throughout the surrounding region. As a safety precaution, routine thyroid checks (for ${ }^{131}$ I deposition) were begun on $T$ P1 ant workers and other 200 East and West Area workers in June 1945. This program continued through mid-1946. Routine urinalys is for plutonium began in May 1946. ${ }^{43}$ In January and February 1945, the initial stack monitoring equipment in the 292-T Building was found to be cross-contaminated and not working properly. Independent test samples run in February showed that the existing calibration factor for this equipment was "low by a factor of 500 ," and it was adjusted in March. Although new tests revealed correlations within a factor of three, the equipment was not considered reliable, and its use was abandoned on a routine basis in June 1945.44 
In the autumn of 1945, radiation levels in the $T$ Plant exhaust fans, measured at the inspection plates on the electrical fan housings, reached $8,000 \mathrm{milli}$ rad per hour (mr/hour). As a result, the fences around the fans were moved outward, and an earth barricade was placed inside the fence to shield personnel walking near the north boundary. Additionally, locked gates and fenced lanes were erected leading to both the 291-T Exhauster Building and to the 292-T Exhaust Gas Laboratory. According to duPont, the new arrangements prevented "the risk of personnel wandering into the area around the electrical fans... where dangerous levels of activity existed." Special Work Permits were required for servicing both the 291-T and 292-T-structures. The following spring, lead shielding was installed around the emergency steam fan in the 291-T Exhauster Building, "to prevent an intolerable radiation condition in the fan house, should the emergency fan be operated." Also, improvements were made in the techniques for remote oiling of the fans. ${ }^{46}$

During the same period, H.I. Section studies extended further into the region adjacent to HEW. In the spring of 1945, according to duPont, "detectable quantities of radioactive iodine were found [by $H$.I. monitors] as far afield as Richland." By autumn, "the widespread deposition of ${ }^{131}$ I on the ground led to a study of its accumulation in terms of micrograms of vegetation." In December, an "activity increase [on vegetation surrounding HEW] accelerated the already considerable interest in the iodine problem, and led to a calculation of the hazard to animals grazing on contaminated plants." In the spring of 1946, the "search for contaminated vegetation was extended until positive samples were found up to 150 miles radius." With the extension of cooling times for irradiated metal that began in December 1945, "radioiodine concentrations on the ground in Pasco, Kennewick and Benton City fell steadily but did not reach the estimated permanently safe level of $0.2 \mu \mathrm{c} / \mathrm{kg}$ [microcuries per kilogram] until Apri1."47 Concurrently, throughout the 1945 and 1946 period, studies by Hanford's H.I. personnel and other MED officials continued into the effects of ${ }^{131}$ I on animals and vegetation at and near HEW. ${ }^{8}$

The one-year period that began on September 1, 1946, witnessed tremendous changes at the HEW. On that date, the duPont Corporation left the Site as prime contractor and was replaced by the General Electric (G.E.) Hanford Company. At the same time, the old MED was concluding its stewardship of the nation's atomic facilities, because the Atomic Energy Act of 1946 (the McMahon Act) had been signed into law on August 1. On January 1, 1947, the new civilian-controlled AEC would take control of the atomic sites, shortening Hanford's name to the Hanford Works (HW). These changes symbolized new hope at Hanford that the Site would not follow the path of so many wartime ordnance plants and close completely. The uncertain future of atomic energy, debated so fiercely throughout late 1945 and all of 1946 at the United Nations and in the U.S. Congress, finally had direction.

Businesses in the Hanford region, which had languished as half of Hanford's work force (5,000 people) left or were laid off in the 15 months that followed the war's end in August 1945, revived. The economic and nuclear production booms assumed enormous proportions in the late summer of 1947 as a giant expansion of the HW facilities was announced to the public. The G.E. Hanford Company, following urgent orders from the $A E C$, was rushing to build two new production reactors (H and DR), as well as the first continuous action, solvent extraction chemical processing plant in the world (the 
WHC-MR-0452, ADDENDUM 1

Reduction-0xidation [REDOX] Facility), 42 additional underground tanks for the storage of high-level wastes, many ancillary and support facilities, and new housing in Richland. Additionally, special nuclear weapons material production goals for HW increased sharply.

As the processing workload on $T$ and B Plants increased in late 1947, so did airborne emissions of ${ }^{131} I$ and other contaminants. Although the metal cooling time was increased early that year to between 60 and 90 days on a routine basis, H.I. monitors still found "areas at times which have [activity] levels above the tolerance level of $0.2 \mu \mathrm{c} / \mathrm{kg}$... [including] communities of Pasco, Kennewick, Benton City and Richland. "50 Although vegetation contamination levels for ${ }^{131}$ I fell to within the range defined as tolerable during the second and third quarters of 1947, they rose sharply with the fourth quarter production expansions. According to HW scientists, these increases occurred throughout "a rather wide expanse of privately owned agricultural lands of Washington, Idaho and Oregon." During that year, an estimated 24,000 $\mathrm{Cl}$ of ${ }^{131} \mathrm{I}$ were released from the stacks of $\mathrm{T}$ and B Plants. 51 In the meantime, in the summer of 1947, a Site chemist developed a method for measuring the deposition of airborne plutionium (from 200 East and West Area stack gases) on desert plants. However, a colleague was quick to point out that sample measurements for this contaminant were nearly meaningless in themselves: "Nothing can be stated with absolute certainty for several reasons. Little, if anything, is known about the rate or method of deposition of piutonium from air on or in vegetation. "52

Another new problem concerned "specks" (particles) that were observed near the $T$ and $B$ Plant stacks beginning in the autumn of 1947 . It was estimated that the specks were being emitted at the rate of 10 to 100 million per month from each of the two facilities, with areas of highest deposition near the stacks, receiving as many as 50 particles per square foot (psf). Analysis by Hanford's laboratories showed that while the specks contained some ${ }^{131} 1$, other fission product and chemical constituents were more important. These included ${ }^{144} \mathrm{Ce},{ }^{90} \mathrm{Sr}$, yttrium, ${ }^{106} \mathrm{Ru},{ }^{137} \mathrm{Cs}$, and the carbon, iron, silicon and hydrogen components of the resin paints used in World War II to coat the insides of the 291-T and 291-B stacks, fans, and duct work. It was the paint constituents that gave HW officials the insight to unravel the puzzle. "The condition described is not consistent with accepted operating standards of contamination control... and therefore constitutes a serious health hazards requiring the utmost expediency in its correction," decreed facilities manager, W.K. MacCready, on November 3. He ordered the replacement of the duct work, fans, and fan casings in the 291-T and 291-B Facilities, as well as the installation of both temporary and permanent "water scrubber" air filters between the fans and stacks and in the individual cell exhaust ducts in $T$ and B Plants. The temporary filters were to be capable of handling $30,000 \mathrm{ft}^{3} /$ minute of offgas flow, and the permanent ones were to be able to scrub the full $60,000 \mathrm{ft}^{3} /$ minute stack flow.

By early 1948, however, the problem was seen as more intransigent. The fans and duct work in the 291-T and 291-B Facilities had been replaced by March, and it had been determined that the installation of the scrubber filters could not be completed before another four to six months. Also, further examination of the material exiting the $T$ and $B$ Plant stacks had shown the presence of "droplets" or "acid mists" from condensed or coalesced process gases. Like the particles, these mists contained activation products and 
oxides of nitrogen. Therefore, it was decided in the spring of 1948 to add huge sand filters below ground near the plant stacks and to reroute the process gases through them. Sand filter installation was completed at $\mathrm{T} P \mathrm{Pl}$ ant on October 15, 1948, and was finished at B Plant 15 days later. Additionally, between April and November 1948, a series of 11 special air monitoring stations were emplaced around the northwest, specifically to monitor for stack particulates. Three of these stations were located at Richland, Pasco, and Benton City, but the remaining eight stretched in a huge trapezoid from Great Falls, Montana, to Bolse, Idaho, to Klamath Falls, Oregon, to Stampede Pass, Washington. Also, biological monitoring for particulate deposition and effects, using rabbits, was initiated in the vicinity of the 200 East and West Area stacks.

The sand filters themselves consisted of successively finer gradations of sand, placed in a large underground container (110 ft by $48 \mathrm{ft}$ ) at T Plant, and equipped with air distributors, plenum chambers, and duct work.

Offgasses from $B$ and $T$ Plants entered the filters via large manifolds that extended along the long side bottoms of the filters and moved progressively upward through layers of concrete blocks, coarse aggregate, and then fine sand at the top. A large plenum chamber at the top of each filter then led the gases horizontally toward duct work leading to the stacks. However, the sand filters were only marginally successful because the sand beds plugged, and the resistance (pressure drop) within the unit increased rapidly. In December 1949, when filter efficiency dropped markedly, it was learned that excess humidity in the system further lowered filter effectiveness. By April 1950, the filters had been dried out, and equipment to measure humidity levels was installed in late 1950. Soon fiberglass filters, consisting of glass filaments one to two microns in diameter, were added in the dissolver offgas lines themselves. Electrostatic precipitators and cyclone separators also were tested as means of filtering particles from $B$ and $T$ Plant gases, but these methods showed mixed or marginal results. "High radioactive particle content" in the air around the 200 East and West Area stacks and throughout the region remained a problem through at least 1953.

As work went forward to address the particulate and acid mist airborne difficulties emanating from the $T$ and $B$ Plant stacks during the period from 1948 to 1950, the offgas iodine problem also was receiving attention. The time frame also witnessed a dramatic increase in the output of irradiated metal from the HW production reactors. In July 1948, B Reactor, closed since 1946, was reenergized. In October 1949, the new $H$ Reactor went on 1 ine, as did the new DR Reactor exactly one year later. The activation of these units brought the total number of operating Hanford reactors to the (then) all-time high of five. Further, in April 1949, experiments began to increase the operating power levels of the oldest HW reactors above the ir World War II design levels of $250 \mathrm{MW}$. A year later, these experiments were so successful that $\mathrm{pl}$ ans were being made to take $B, D$, and F Reactors to $600 \mathrm{MW}$. ${ }^{56}$ With the new REDOX processing plant not scheduled to go on line until early 1952 , the workload on $T$ and $B$ Plants rose substantially. At the same time, in early 1948, a key subcommittee of the National Committee on Radiation Protection (NCRP) was taking steps to reduce the "tolerance value" of "131 I to man by a factor of 10. In view of these developments, along with continued "scattered readings... of the off-area contamination of vegetation...two to two and a half times the estimated tolerable limit of $0.2 \mu \mathrm{c} \quad{ }^{31} \mathrm{I} / \mathrm{kg}$, "Hanford's chief health physicist, Herbert M. Parker, recommended an increase in metal cooling times 
beginning in April 1948. This suggestion was adopted Immediately by Site management. The aging period for irradiated fuel elements rose to between 90 and 125 days and remained there for most of 1948, 1949, and early 1950.57

Additionally in 1948, the AEC established a Stack Gas Working Group of prominent industrial health specialists from around the nation, to "make a concerted and full-scale attack on solutions to various existing stack gas problems." While the Group was to address difficulties throughout all AEC installations, it was instructed that "Hanford is to have top priority." During its initial Site tours and meetings in the summer of 1948, the Group discussed Chemical Warfare Service (CWS) filters, electrostatic precipitators, submerged porous plates, cyclone equipment, and many other new technologies including "ultrasonics." However, caustic "water" scrubbers and sand filters were considered to be the best available and practical means to deal with the huge volumes and high radioactivity levels of the $T$ and $B$ Plant stack discharges. By summer's end, the Group also had recommended "that sampling techniques should be improved and that evaluation of the problem should continue." At that time, they had "no specific further recommendations." 58

Despite the best efforts of the Stack Gas Working Group and HW scientists, no truly effective chemical or physical barriers to control the activity levels in T and B Plant stack emissions were identified in 1948 or 1949. Additionally, during the summer of 1948, the NCRP voted to reduce the permissible 1 imit for ${ }^{131}$ I not by a factor of 10 , but by a factor of 25 . At the same time, Hanford's tolerable level for ${ }^{131}$ I contamination on vegetation was halved, to $0.1 \mu \mathrm{Ci} / \mathrm{kg}$. Metal cooling times purposely were kept long, and 131 I emissions at the Site were held to approximately $1,200 \mathrm{Ci}$ throughout 1948. The 1949 discharge levels, likewise, remained low until December, when a single event at $T$ Plant allowed the escape of nearly $8,000 \mathrm{Ci}$ of ${ }^{131} \mathrm{I}$ in a two-day period. This event, known as the Green Run, boosted the 1949 emission level to approximately $12,000 \mathrm{Ci} .59$

The Green Run was so named because it involved the experimental dissolving and processing, at $T$ Plant, of irradiated metal that had been aged only a short time (i.e., that was "green" or newly irradiated). The -vent occurred just three months after the United States had learned that the Soviet Union had achieved atomic weapons capability by detonating its first nuclear test bomb over Siberia. The initial U.S. detection of this test had come via Hanford's network of ${ }^{131}$ I monitoring stations. According to the General Accounting Office, the Green Run was an instrument development test that "was al so generally related to research into the safety and health effects of nuclear detonations and nuclear production operations." The event was directed by the U.S. Air Force and involved the dissolving of 1 ton of fuel elements that had been pushed from a Hanford production reactor on November 17. As such the metal had been aged only 16 days, al though original plans had called for metal that had been cooled 20 days. A special and extensive monitoring effort was established in the Hanford region, involving taking over 100,000 samples within the few days that followed the test. 60

Effects of the Green Run on contamination levels on regional vegetation, in rainwater and mud, and in other environmental media were dramatic. Rain and snow moved into the area just a few hours after dissolving began on the 12 (midnight) to $8 \mathrm{a} . \mathrm{m}$. shift on December 2. Vegetation samples taken in the Tri-Cities and Benton City demonstrated average activity levels from 8.3 to 
$61.7 \mu \mathrm{Ci} / \mathrm{kg}$, with the highest reading in Kennewick showing $107.3 \mu \mathrm{Ci} / \mathrm{kg}$. The latter reading was over 1,000 times the (then) tolerable 1 imit of $0.1 \mu \mathrm{Cl} / \mathrm{kg}$. An elliptical zone of contamination was detected, encompassing the Hanford Site, as well as areas to the northeast and southwest. Communities up to 70 miles from HW displayed readings from 2.0 to $5.0 \mu \mathrm{Ci} / \mathrm{kg}$, while Walla Walla eyidenced values from 5.0 to $10.0 \mu \mathrm{Ci} / \mathrm{kg}$. Animal thyroid values for beta ( ${ }^{131}$ I) activity within 70 miles of HW averaged 14 times higher that December than they had in october. According to Hanford's AEC manager, the Green Run "reaffirmed that ${ }^{131}$ I will contribute the greatest difficulty upon dissolving metal cooled for such a short period. ${ }^{61}$ In the years since this controversial test was. made public in 1986, the level of public interest in it has remained high. ${ }^{6}$

Following the Green Run, metal cooling times at Hanford returned to the 90- to 125-day range throughout the first eight months of 1950. However, a major discovery in "I31 control was made during that period. "Silver reactor" filters, so called because they contained a bed of fiberglass material soaked with silver nitrate that would react with radioiodine to form silver iodide, were developed and tried on an experimental basis. The tests worked so well that such filters were installed at B and T Plants in October and December 1950, respectively. The equipment was placed in the ducts that led out of the dissolver cells and into the main plant exhaust lines. Sampling equipment first was placed in the 292-T and 292-B Buildings but too much acidic condensate formed in the 265-ft length of dissoiver vent line. At the end of the year, the sampling equipment was moved into the pipe galleries of $T$ and B Plants. Hanford officials anticipated good results from the silver reactor filters, and they were anxious to increase production in view of tense international developments, specifically the onset of the Korean War in June 1950. As a result, they began in September 1950, a series of experiments in shortening metal cooling times. That month, the aging period was dropped to 70 days, but a quick rise in ${ }^{131}$ I emissions drove the period up to 78 days for the remainder of the year. ${ }^{63}$

When the filters were installed, initial reports prepared in January and February 1951 placed their efficiency rate for ${ }^{131}$ I removal at $99.9 \%$. Although they were not positioned to entrap the small portion (approximately $10 \%$ ) of ${ }^{131}$ I that escaped from the plutonium-bearing solutions in the plants after the dissolving phase, filter performance was so encouraging overall that metal cooling times at HW were dropped to 67 days in mid-February. Decay periods were lowered further in March and then decreased to an average of only 48 days in Apri1. During these months, the average emission level for ${ }^{131}$ I hovered between 2 and $5 \%$ of that which was evolved in the dissolver c=ils of $T$ and B Plants. In late April, however, H.I. monitors reported a "material change in the efficiency of the silver reactor." By mid-May, with cooling times ranging between 44 to 55 days, the average fraction of evolved ${ }^{131}$ I that was released to the atmosphere had risen to $25 \%$. In one dissolving, as much as $34 \%$ was released. Additionally, with the greater throughput of irradiated metal, more ${ }^{131}$ I was being generated than ever before at HW. The amount of total released curies soared to an average of 181 per day throughout the spring, with a one-day maximum of $425 \mathrm{Ci}$. At $T$ Plant, a summer production test was planned to determine whether ${ }^{131}$ I evolution could be suppressed by the addition of mercury to the metal dissolving solution. However, by late July, H.I. monitors reported that the silver reactor filters were "easily saturated" and "failing." The filters serving Cells 4 and 5 Left and 3 to 
5 Right in T Plant were replaced when they overheated and again showed good results. However, in view of the overall performance record of the silver reactor filters, metal cooling periods were lengthened to 80 to 100 days at $\mathrm{HW}$. Atmospheric emissions of ${ }^{31} 1_{1}$ then fell to an overall average of $5 \mathrm{Ci} /$ day throughout the fourth quarter of $1951 .^{64}$

The 1950 and 1951 experiments in shortened metal cooling times were clearly reflected in the radioiodine discharge levels and in the vegetation and animal thyroid activity levels in the Hanford region. In total, the years 1950 and 1951 witnessed the airborne discharge of approximately $2,100 \mathrm{Ci}$ $\left({ }^{131} \mathrm{I}\right)$ and $18,700 \mathrm{Ci}\left({ }^{131} \mathrm{I}\right)$, respectively. Activity density on vegetation in Richi and averaged $0.16 \mu \mathrm{Ci} / \mathrm{kg}$ throughout most of 1950 (only slightly above the then-tolerable limit of $0.1 \mu \mathrm{Ci} / \mathrm{kg}$ ) but averaged $0.4 \mu \mathrm{Ci} / \mathrm{kg}$ by April 1951. As the result of dissolver problems at $T$ Plant and the REDOX Plant that spring, values jumped to $2.5 \mu \mathrm{Ci} / \mathrm{kg}$ in June 1951, with one sample in Kennewick demonstrating $23.0 \mu \mathrm{Ci} / \mathrm{kg}$. Likewise, animal thyroid samples taken up to 200 miles from HW revealed sharp rises in beta ( $\left.{ }^{131} \mathrm{I}\right)$ activity levels during the second and third quarters of $1951.65^{\circ}$

Throughout the next few years, Hanford scientists learned that the silver reactor filters worked well, as long as they were replaced and/or regenerated (i.e., sprayed with additional silver nitrate) on a frequent basis. Additionally, operating experience showed that the filters worked best when the gas was heated to approximately $375^{\circ} \mathrm{F}$ (Fahrenheit), instead of at the mid-1951 levels of 400 to $478^{\circ} \mathrm{F}$. Silver reactor filters became the standard and best means of control for ${ }^{131} \mathrm{I}$ to be used at $T$ Plant (and the remainder of the Hanford Site) throughout its operating history. However, after 1951, $T$ Plant did add mercury, silver, potassium, and/or sodium to the metal dissolving solution to help keep iodine in solution and to provide added means of emission control. Throughout the remainder of $\mathrm{T}$ Plant's years as a chemical processing facility, metal cooling times were maintained between 90 and 110 days. Average total ${ }^{131}$ I emissions from HW hovered around $2.8 \mathrm{Ci} /$ day and sometimes reached as high as $4.2 \mathrm{Ci} /$ day but almost never achieved the target rate of $1.0 \mathrm{Ci}$ that had been established by the H.I Division. During early 1955, T Plant experienced a spike in the amount of ${ }^{131}$ I released from its stack, and subsequent investigation revealed malfunctions in the dissolvers in Cells 3 through 5 Right. That summer, in the midst of a special nuclear defense materials push undertaken by President Eisenhower, the question of shortening metal cooling times was again debated at HW. A "Symposium on the Iodine Problem" was held, but none of the speakers could affirm the safety of reducing the decay period to 70 days, because dependable countermeasures were not at hand. ${ }^{66}$ 
WHC-MR-0452, ADDENDUM 1

This page intentionally left blank. 
WHC-MR-0452, ADDENDUM 1

\subsection{T PLANT'S TRANSITION: THE END OF THE CHEMICAL PROCESSING MISSION}

Throughout the 1940s, the efficiency of the bismuth phosphate process continued to improve at T Plant and at B Plant (the other active, World War II chemical separations canyon at Hanford). By 1950 , the Hanford ${ }^{239} \mathrm{Pu}$ production rate had increased by $299 \%$ over the 1946 rate, and research and development had cut the processing time cycle by $45 \%$. Additionally, process improvements had decreased the amount of fresh chemical materials needed, so that despite higher material costs, expenses for fresh chemicals were reduced by $25 \% .67$ Plutonium production at Hanford continued to increase in 1951, and in 1952, with the completion of C Reactor, it rose another 44\% over 1951. By that time, the production rate stood at five times that of 1947 ! In the early 1950 s, underwater repair facilities for failed cell connectors and other equipment pieces were installed in Cell 4 , to avoid unnecessary shutdowns. Although $T$ Plant adapted its processes to handle metals irradiated to many different goal exposures, and learned to optimize batch size and minimize time cycles, its importance diminished with the startup of the REDOX Plant at first location (reduction oxidation) chemical processing plant in January 1952. The new plant was much more efficient because it operated with a continuous action, solvent-extraction chemistry and it salvaged most of the uranium that was not converted to plutonium. ${ }^{8}$

In 1953, overall HW plutonium production rose by $38 \%$ over that of 1952 , with $88 \%$ of the processing being conducted in the REDOX Plant. T Plant accounted for the remaining $12 \%$ because $B$ Plant had shut down shortly after the REDOX Plant began operations. ${ }^{69}$ Plutonium production continued its dramatic rise at Hanford throughout the 1950s. The rate for 1954 exceeded that of 1953 by $26 \%$. A $30 \%$ rise in processing capacity was realized at $T$ Plant, with the acquisition of a third metal dissolver in August and a third extraction unit in December. A program to reactivate $B$ Plant, known as the 4X Program (because it would use four of Hanford's processing facilities for active chemical separations) was initiated. Design and proposal work was approved, and the construction work needed for reactivation was begun in December $1954 .^{70}$ The B Plant renovation work was completed one year later. During the same time frame, a combined operation of $T P I$ ant and $U P 1$ ant, to be known as the TBX Plant, also was studied. In this plan, metal dissolution and process feed preparation would take place in $T$ Plant, while separation and decontamination would take place in U Plant. While such studies went forward in 1955, T Plant operations were characterized by increased time cycle efficiency, to the point where the average processing time cycle dropped to 4.5 hours. The overall HW production rate increased by $30 \%$ over 1954 ."

By 1956, however, the great processing efficiencies being experienced at the REDOX Plant and at the new Plutonium-Uranium Extraction (PUREX) Plant made the operations of $B P l$ ant and T Plant unnecessary. That year, irradiation processing rates increased by $39 \%$, but chemical processing rates jumped by $59 \%$. The decision was made not to reactivate $B$ Plant, and $T$ Plant was retired from active service as a chemical processing facility in March 1956. During that final month, $T$ Plant dissolved only three batches of fuel elements, and the final plutonium processing run was completed on March 20.72 
WHC-MR-0452, ADDENDUM 1

This page intentionally left blank. 
WHC-MR-0452, ADDENDUM 1

\subsection{CONTAMINATION EVENTS}

The first recorded contamination event in $T$ Plant's history occurred on March 11, 1945, when a "suckback" in the steam jetting lines caused higher than normal radiation levels in the Pipe Gallery and in the Operating Gallery. On June 27, vapor condensate from a process tank backed into a solution addition line in the Operating Gallery and caused levels in that area to exceed tolerance limits. During the same period, some contaminated floor spots were found in the 224-T Building. In July, two separate maintenance operations in that building's $F$ Cell resulted in the spread of "gross contamination over the entire floor area and over much of the equipment." Other maintenance operations in August and October also produced contamination spreads in the 224-T Building. In February 1946, a "trombone" containing a high-level product sample was being carried from $T$ Plant to the 222-T Laboratory when it fell to the ground and "spilled highly active solution." At nearly the same time, a leak in an E Cell spray line in the 224-T Building "disseminated several milligrams of plutonium over the floor... [and] onto the pipe gallery floor." The following month, a leak in a 224-T waste line again "released milligrams of product." At nearly the same time, the most serious contamination event at $T$ Plant up to that date occurred when a maintenance man, the ground, a crane, and diversion box were sprayed with first-cycle waste solution during an attempt to open and free a plugged tie-line from Section 15 of T Plant. One month later, a faulty vent valve on a the Cell 3 to 5 Right gang valve assembly allowed fumes containing radioiodine and nitrous oxide from dissolver Cell 5 to back up into the Operating Gallery.

In December 1947, an operator received contamination on his hands and clothing while "rodding" a vent pipe in the new crib No. 2 near the 361-T Tank. In May 1949, dust blowbacks from improperly sealed burial boxes contaminated equipment burial grounds outside $\mathrm{T} P \mathrm{Plant}$ and spread contamination to several pieces of equipment being used in and near the burial area. In April 1951, an improperly wrapped vent pipe from the 224-T Building's E-Cell resulted in "gross" contamination of two people, their truck, and areas of ground and of the 224-T Building. In November 1952, a large area of ground around the 155-TX diversion box catch tank, six vehicles, two air compressors, a hydrocrane, and various electrical equipment were contaminated during the transfer of a highly acidic, off-standard solution out of this tank. Just four months later, a chemical reaction in the same 155-TX catch tank resulted in another spread of ground contamination. In February 1953, a chemical trainee at the 222-S Laboratory became contaminated when he used improper procedures to transfer samples from $T$ Plant to that laboratory. Three months later, two other chemical trainees, using improper procedures, dropped and spilled a supernate sample from the 241-TX Tank Farm on the 200 West Area railroad crossing on 22 nd Street between Bridgeport and Camden Streets. ${ }^{74}$

On July 3 and 4,1953 , perhaps the most serious contamination event in $T$ Plant history up to that date occurred when a 4-ft-diameter hole caved in over the old 5-6 Cell drainage waste line between T Plant and the 222-T Laboratory. Liquid flow about $200 \mathrm{ft}$ long from the ruptured 5-6 7 ine was visible along the ground just north of and over the 154-TX diversion box, located between the two buildings. Gross ground contamination occurred over this wide area, al though the cause of the pipe rupture was unknown. 
Contamination events multiplied in late 1953 and into 1954, as production increases strained the capacity of plant and support systems. Diversion box catch tank leaks, as well as leaks from 242-T Evaporator steam coils, caused ground contamination spreads in the summer and autumn of 1953 and continued into the spring of 1954. High winds during solid waste burial operations, complicated in one case by the dropping of a burial box and in another case by leaving contaminated materials out overnight while the necessary burial equipment was obtained, brought contamination spreads in large areas north and west of T Plant in November and December of 1953. In January 1954, two employees and a large area of ground were contaminated during the cleanout of pump and sluice pits in the 241-TX Tank Farm. ${ }^{76}$

A serious personnel contamination incident occurred at the 224-T Building in February 1955, when two employees were grossly contaminated (one up to $290 \%$ of the maximum permissible body burden) during the replacement of a dip tube on the $F$ Cell centrifuge. The next day, in a separate incident, a large section of ground around the stack of the TXR Vault was contaminated with particulate matter consisting of activated rust and paint. The TXR Vault had been built in 1952 and 1953, as the place where T Plant high-level wastes from SSTs would be pretreated with nitric acid to be readied for the U Plant Uranium Metal Recovery Mission. In late December 1955, several thousand gallons of first-cycle waste accumulated on the ground between T Plant and the 224-T Building, as a result of a ruptured underground line. This event was the last serious contamination incident that occurred during $T$ Plant's years as a chemical processing facility. In subsequent years, other contamination spreads occurred along rail and other areas near $T$ Plant. In the summer of 1973, the largest high-level waste tank leak in Hanford Site history occurred at Tank 241-T-106. However, the event was unconnected with the ongoing operations of $\mathrm{T}$ Plant. 
WHC-MR-0452, ADDENDUM 1

\subsection{T PLANT'S ROLE AS A DECONTAMINATION FACILITY}

The full process of cleanout and transition to a new role as HW's decontamination facility took several years at T Plant. Washes of the processing equipment and cells with a $60 \%$ nitric acid solution began within 10 days of the March 20, 1956, shutdown. The acid flush material then was collected and processed for plutonium recovery. The initial flush reduced the radiation levels in plant cells by a factor of ten, and subsequent flushes with a solution of $1 \%$ sodium citrate and $5 \%$ sodium hydroxide achieved much smaller (albeit significant) reductions. Between 1956 and 1963, many jet assemblies, jumpers, tanks, tank spargers, dissolvers, centrifuges, heaters, lubricators, pumps, valves, instruments, and other equipment, as well as some piping, were removed from $\mathrm{T} P \mathrm{Pl}$ ant and buried as contaminated waste. In 1958, the facility replaced U Plant as HW's central decontamination plant. Several control panels and other miscellaneous equipment pieces were moved into the plant's head end and stored there. In 1959, two small shacks associated with $T$ Plant were removed to make rocm for construction of the 2706-T Decontamination Annex, a facility that handled equipment too large to be moved into $T$ Plant or pieces having lower contamination levels than those decontaminated in T Canyon itself. As late as the 1964 to 1966 period, World War II processing equipment and instruments still were being removed from $\mathrm{T}$ Plant and buried.

In 1963, all of the chemical, air, steam, and water piping from the Pipe and Operating Galleries of Sections 17 to 20 of T Plant, with the exception of the main air, water, and steam header 1 ines, was removed to make room for offices and a lunchroom for the decontamination facility. The total amount of piping displaced represented approximately $25 \%$ of all such 1 ines in the plant's Pipe and Operating Galleries. The following year, the remainder of the stainless and mild steel piping in Sections 17 to 20 was removed. At the same time, much stainless steel and black iron piping was removed from the Operating Gallery of the 224-T Building and reinstalled as cold chemical addition lines in the same building. ${ }^{9}$ In 1964, a Burst Test Containment Facility was installed in the head end of $T$ Plant, thus providing a place to conduct trials in the explosive degradation of irradiated fuel elements. At that time, all of the dissolvers, condensers, towers, heaters, and silver reactor filters were removed from the 3-5 Right and Left cells and buried. ${ }^{80}$ Two years later, all of the $0.5-i n$. steam condensate piping from Sections 3 through 17 of the Pipe Gallery was removed and buried. ${ }^{81}$ In 1967, Pacific Northwest Laboratories requested space for experimental work in the head end of $T$ Plant. At that time, the panel boards and gang valves from Sections 3 and 4 of the Operating Gallery, as well as miscellaneous stainless steel and black iron pipe and fittings, were removed and buried. Additionally, 800 linear feet of 2 -in. steam piping from the gang valves to the wall nozzles, $300 \mathrm{ft}$ of associated conduit and electrical wire, and $200 \mathrm{ft}$ of black iron piping were removed. Many additional pieces of equipment, old instruments, as well as much wiring and additional piping, continued to be removed during 1968 and 1969.

The decontamination operations carried out in T Plant involved several processes. Smaller equipment pieces were immersed in decontamination solutions in "thimble tanks," and larger pieces were flushed with water, chemical solutions, sand blasted, steam blasted, high-pressure sprayed (using 
pressures up to $10,000 \mathrm{psi}$ ), and/or scrubbed with detergents. During the initial years, a strong nitric acid flush (approximately $60 \%$ ) usually began the decontamination process, followed by a caustic wash with sodium hydroxide combined with sodium phosphate, boric acid, versene, sodium dichromate, sodium tartrate, or sodium citrate. However, it was learned that versene and tartrate, in particular, adversely affected the ability of soil cribs to adsorb the rinsate materials. High-pressure sprays often used 1,1,1-trichloroethane or perchloroethylene, and detergents generally were chloride based. By the mid-1960s, commercially prepared and trademarked chemical mixtures had replaced most of the simpler chemicals used in the early years. Many of the commercial products were based on oxalic acid, phosphates, nitric acid-ferrous ammonium sulfate combinations, potassium permanganate and sodium bisulfate, with some unknown additives. Filtration of airborne effluents associated with decontamination activities was accomplished through the sand filters. ${ }^{83}$

Decontamination operations carried out in T Plant demonstrated their economic value early. In just the first year, savings over nearly $\$ 225,000$ were shown in plant records, based upon the depreciated value of used equipment cleaned and returned to service. By 1969, monthly savings usually were valued at between $\$ 100,000$ to $\$ 200,000 .{ }^{84}$ Most equipment needing decontamination was transferred to T Plant in "multi-purpose transfer boxes," flat rail car-mounted containers made of welded stainless and carbon steel. However, some very special transfers occurred to and through $T$ Plant during its years as a decontamination facility. During the late 1970s, the T Plant rail entry tunnel and pool cell were used to receive, unload, and disassemble high-exposure, irradiated fuel from the Shippingport (Pennsylvania) power reactor. In 1983, the T Plant rail entry tunnel again was used to receive and transload (into overpack burial containers) zeolite beds encased in stainless steel liners and loaded with ${ }^{137} \mathrm{Cs}$ from the Three Mile Island (Pennsylvania) power reactor. Following an accident in that reactor in 1979, the zeolite beds had been used to absorb ${ }^{137} \mathrm{Cs}$ out of the contaminated water in the reactor coolant system's containment sump. In 1983, the Submerged Demineralized System (SDS) liners came to Hanford for burial as contaminated waste. During 1982 and 1983, several improvements were made to the T Plant crane and cab, filtration system, instrumentation, and rail tunnel, in preparation for this project. 


\section{WHC-MR-0452, ADDENDUM 1 \\ 15.0 1990S BRING NEW CHALLENGES AND OPPORTUNITIES TO T PLANT}

On October 24, 1990, a Continuous Air Monitor (CAM) at T Plant was silenced by the use of a stick and a chair. A subsequent investigation reported the incident as indicative of procedural deficiencies, poor work practices and training, inadequate communications of management expectations, and deteriorating physical conditions in T Plant. Eight other incidents in quick succession that autumn and early winter led to a decision by operating contractor Westinghouse Hanford Company (WHC) to curtail operations. As of January 9, 1991, T Plant was ordered to accept no new work and to focus its sole efforts on upgrading the facility and the operating practices "to acceptable levels." 86

An Unusual Occurrence Report entitled "Limited Decontamination Operation," issued later that month reiterated the problems endemic at T Plant: "The facility has been allowed, due to resource limitations, to deteriorate over a period of years... Equipment has not been serviced or replaced with the regularity necessary to provide reliable service. Procedures have not been revised... Personnel training has been insufficient." The award fee from the U.S. Department of Energy (DOE) for the six-month period covering October 1990 through March 1991, likewise pointed to the alarm disabling as a tip-of-the-iceberg event reflecting "systematic neglect by the line organization over a substantial period of time." A DOE Conduct of Operations inspection of $\mathrm{T}$ Plant, carried out during this time period, "displayed all areas to be in noncompliance." 87

At nearly the same time, WHC organized a T Plant Future Assessment Task Team to determine the future decontamination needs of the Hanford Site and to delineate T Plant's role in filling those needs. A facility manager was named, along with a new staff of people dedicated and excited by the immense challenges of rehabilitating the historic plant. ${ }^{88}$

Thus began the long road back for T Plant. In June 1991, the Task Team concluded that a centralized decontamination facility was essential to the Hanford Site cleanup mission, both for reasons of safety and economy. Hazardous and radioactively contaminated objects would face almost insurmountable regulatory barriers if they were to be shipped offsite for decontamination. Further, the costs of onsite decontamination would pay large dividends both in instances where equipment was returned to service and in cases where objects were reduced in radiation and chemical levels low enough that they could be buried as low-level waste or released as nonregulated scrap. Because the cost of burying low-level waste is approximately one-third that of storing high-level or mixed waste (and there are additional costs for ultimate disposition later), it quickly became obvious that an upgraded $T$ Plant had an important role to play in Hanford's future. ${ }^{89}$

In the meantime, the T Plant staff was busy evaluating the facility and beginning improvements. The lack of updated, usable, as-built drawings jumped out as an immediate problem. Eventually, 2,600 drawings applicable to T Plant were identified, nearly all of them dating from an original set developed in World War II to cover T, B, and U Plants as a unit. Over the years, engineering change notices (ECNs) applicable to any one of the three plants 


\section{WHC-MR-0452, ADDENDUM 1}

had been entered in pencil on the drawings, even though these facilities soon diverged widely in equipment, missions, and modifications. The result was a master set of drawings that described none of the plants as they really existed.

The T Plant staff selected approximately 500 of the most important old drawings, let a subcontract to enter them into a modern, computerized system, and updated them through a series of thorough "walk-downs" of the facility. At the same time, a unique identifier system of coded labels was developed for each component of the steam, water, air, drain, ventilation, process, and instrumentation systems. Entered onto the updated drawings, as well as onto the physical components in the plant, these identifiers completed the process of making the drawings unique to $T$ piant. They also made it possible to write accurate new procedures for facility activities, and to implement a specific and workable Lock and Tag system. Additionally, a "worker-friendly" set of systems drawings were developed, designed to represent various single systems in schematic fashion, thus making it easier to perform maintenance work and other routine inspections.

Another set of problems discovered early by the new T Plant staff was that concerning safety documentation. The facility was operating with a conglomeration of documents that included an old Safety Analys is Report (SAR) with many supplemental ECNs that had not been incorporated into the original, three sets of Operational Safety Requirements (now called Technical Specifications or "tech-specs"), and five Operating Specifications Documents (OSDs). None of these documents had been approved officially by DOE.

Studying this maze, the staff began a process of both excising the irrelevant portions contained in the many documents and consolidating duplicate or overlapping material. At the same time, they incorporated the findings of the criticality safety evaluation report completed on the facility in 1989 and 1990. The result was the adoption of a single SAR by mid-1993 (with some chapters still being revised in early 1994); a single, consolidated OSD; and two smaller documents relevant to the 72 irradiated fuel assemblies from the Shippingport reactor that have rested in the $T$ Plant pool cell since $1978 .{ }^{90}$ Both documents relative to the fuel assemblies will be incorporated into the consolidated documentation during 1994.

One more early activity flagged with a high priority was the inspection of the pool cell, known as the pressurized water reactor (PWR) pool because of the presence of the Shippingport fuel elements. The water storing the rods appeared unclear and was covered with floating debris. However, some preliminary cleaning and the addition of new screening and filtration devices showed that the pool itself was basically sound. A waste minimization initiative was made to replace or possibly eliminate antique refrigeration units that had been needed to chill the pool's water and, thus, eliminate some of the secondary cooling water discharges to the 216 T-4 Ditch. Additionally, new level instrumentation, covering the entire pool depth instead of just the 4-in. band covered by older instrumentation, was designed and installed. Lastly, firm administrative controls were placed on the water levels required in the pool. 91

At the same time, a complete radiological survey of $\mathrm{T} P 1$ ant was carried out, and physical cleanup got underway. Staff "living" areas (e.g., offices, shower rooms, bathrooms, and change facilities) were given first priority. 
The program that had built the experimental laboratory into $T$ Plant's head end in the 1960 s had abandoned the facility, leaving a substantlal supply of chemicals. The cleanout of this area revealed a vast array of substances now defined as hazardous, including some shock-sensitive chemicals that had to be detonated under controlled conditions.

Existing office space on the second floor of the 271-T Butlding was repainted, carpeted, and wired to accommodate modern computers and other office machinery. In the same building, an old electroplating shop, containing many hazardous substances, was cleaned out to serve as a consolidated lunchroom. The new lunchroom was needed to address safety and radiological control issues associated with five older lunch areas. Two new change tratlers were emplaced to serve the 2706-T Building and the rail tunnel to improve radiological controls and to allow radiation zone reductions in these areas. Additionally, design was begun on a large "entryway" project, prompted by safety concerns associated with the then-unregulated access to the 221-T Building. Personnel radiation monitoring devices were emplaced to survey each person before leaving the plant, and a visitor identification and check-in office was established by early 1993 ."

In early 1992, the cleanup and cleanout of the 2706-T Decontamination Annex began. Many boxes and drums containing unknown wastes had been stored in the facility over the years. One such drum, moved outside to await disposition, developed a leak that brought inspectors from the Washington State Department of Ecology (Ecology) in May 1992. Several deficiencies were noted in the yard area outside of the 2706-T Building and the T Plant rail tunnel, all concerning noncompliance with waste accumulation, storage, administrative control, and record-keeping regulations. The T Plant staff began an ambitious program to open, sample, characterize, label and disposition every box, drum, and equipment piece at the facility. Contaminated items were carried into the $T$ Plant rail tunnel, and much of the sampling was done with the aid of Hanford's Sampling and Mobile Laboratory Group. The three most corroded drums were inspected by the Site's Hazardous Materials Team. When highly acidic contents were identified, the contents were treated, the drums were overpacked, and dispositioned as hazardous and radiological waste. In January 1993, Ecology and WHC conducted a follow-up inspection of the 2706-T yard and confirmed that the noncompliance issues of the previous spring had been "satisfactorily completed." 93

At the same time, T Plant officials had learned from dealing with their own noncompliant waste drums and boxes that they could perform a valuable service for the rest of the Hanford Site. To receive, store, contain, and perform some minimal waste treatments (e.g., liquid absorption from containers), T Plant applied for and received an expanded Part A Dangerous Waste Permit in September 1993. The permit al so identified waste management activities supporting the facility's long-term mission in waste storage and treatment, in tanks, containers, and other units.

Waste inspections and repackaging then became an important part of the $T$ Plant mission, as the facility stepped up to accept, open, sample, and repackage over 200 drums containing unknown wastes from the Tank Farms in 1993. Work also was completed on an inventory of 58 boxes of unknown Tank Farms waste, and an agreement was reached to help sort, sample, and repackage part of a huge inventory (over 2,000 boxes and drums) of other Tank Farms 
containers found to be in violation of Washington State codes in 1992. The avallability and sultability of $T$ Plant for this work soon became a key factor in the ability of WHC and the Ecology to reach agreements on Hanford's backlogged and unpermitted waste containers. ${ }^{94}$

In the meantime, rehabilitation of the 2706-T Facility, where unfiltered, open-air decontamination activities had taken place, continued throughout 1992 and 1993. A high-efficiency particulate air (HEPA) filtration system was installed, along with new doors with tight seals, a fan room to provide for negative air pressure in the facility, air monitoring equipment, new floor grates and drains, an automatic fire sprinkler system, and new ilighting. Procedures for the facility were rewritten to meet current standards, and training packages were developed to ensure safe operation of the facility. DOE Readiness Reviews certified the 2706-T Building as capable of limited operations in 1993 and for full-scale operations in early 1994."

When the cleanout and refurbishment of the 2706-T Facility was well under way, the T Plant staff turned its attention to the main canyon, the in-plant tanks, and the galleries. Inspection of the in-plant tanks and piping revealed the inability of these single-walled vessels to meet modern regulatory codes. New transfer piping leading to the rail loading area, where rail cars are filled with decontamination waste liquids destined for the Tank Farms, was needed. The galleries contained extraneous pipes and process control equipment, much of which was insulated with asbestos, as well as obsolete and underpowered electrical connectors and clutter of various types.

The canyon "deck" itself was littered with old pumps, racks, hoses, old processing equipment in various states of repair and disrepair, including jumpers, pulsers, motors, transformers, shields, pallets, tanks, and many other items. Most prominent amidst the canyon debris were the components of the "Hot Spares Train," and two large "drag-off" box liners. The latter were the stainless steel shells from inside concrete waste containers approximately $8 \mathrm{ft}$ by $8 \mathrm{ft}$ by $16 \mathrm{ft}$. The components of the Hot Spares Train (known as the "Circus Train" by Hanford workers) were several used towers and process tanks from the PUREX facility, brought to T Plant in early 1990 after a series of transportation mishaps that brought the nickname. ${ }^{96}$

During 1993, the first drag-off box liner was emptied, sorted, and the wastes were segregated, repackaged, and dispositioned according to the appropriate designation. Work to characterize the contents of the second drag-off box liner, known to contain at least one item providing significant potential radiation dose, also was initiated in 1993. An initial attempt to remove contaminated equipment from this liner resulted in high radiation levels. Complete repackaging of this liner in 1994 is crucial to readying the canyon deck for future operations. The components of the Hot Spares Train, also likely to contain significant radiological contamination, likewise remain a crucial puzzle that must be tackled in 1994. Radiological and physical characterization and discussions with the regulators will help to determine whether the parts are cut up and partially decontaminated and buried, or whether they are sealed and transported to the PUREX tunnels or to some other final disposition site. ${ }^{97}$ 
Looking to its future, T Plant currently has many upgrades projects under way. Among the largest is a multimiliion dollar addition to the 291-T Stack ventilation system, replacing and augmenting the fans that circulate the $T$ Plant canyon air system. Other extensive upgrades will add capacity to the primary power systems and motor control centers of $T$ Plant. An approximately \$15-milition project will provide modern collection tanks with secondary containment and leak detection capacity for in-plant, liquid mixed wastes, as well as two collection tanks in the 2706-T yard and one large tank in the 2706-T rail pit. Additionally, a moveable holst is planned for the 2706-T Building, to ensure that decontamination workers and equipment could reach any angle needed to perform work on odd-shaped equipment.

other plans are being developed to provide low-level decontamination services for a variety of needs, including verification sampling of mixed wastes, waste repackaging, disposition of $T$ Plant backlog waste, and refurbishment of well drilling rigs, cranes, trucks, tankers, and other equipment used in the course of the Hanford Site cleanup. Preparations are under way for high-level decontamination operations to process contaminated canyon deck equipment. Additionally, a WesTIP (Westinghouse Technologies to Improve Processes) workshop recently was held to discuss the integration of customer, regulator, servicer, and other needs in decontaminating Tank Farms long-length equipment in T Plant. A transfer port to bring in odd-shaped or oversized contaminated equipment i.s being designed for the tail (southwest) end of T Plant. 98

When the cleanout and upgrade projects are completed at T Plant, some standard decontamination techniques will be used, including steam and water sprays, vacuum cleaning, chemical and detergent scrubs, electropolishing, various soaks accompanied by ultrasonic agitation, and others. Currentiy, an "ice-blaster" for decontamination work has been procured for the 2706-T Facility, and a cutting shear is being considered for the 221-T Canyon. Also, innovations, such as steel "greenhouse" enclosures for separate stations within the canyon, are possible. Additionally, thought has been given to cleaning nut some of the cells themselves, lining them with steel, and setting up specialized work areas with robotic systems to perform the highest level work. Present1y, customers from all over the Hanford Site, especially the Tank Farms, are pressing $T$ Plant to begin performing decontamination work on high-level "debris" and on a wide variety of equipment pieces. As quickly as it can meet regulatory requirements for safe operations, this historic $p$ lant $_{9 q}$ will make a significant contribution to Hanford's environmental cleanup.

1 WesTIP is a trademark of Westinghouse Electric Corporation, of Pittsburgh, PA. 
WHC-MR-0452, ADDENDUM 1

This page intentionally left blank. 
WHC-MR-0452, ADDENDUM 1

\subsection{REFERENCES}

Full citations to the following references are found in the Bibliography, Section 17.0 .

1. duPont, Construction, Vo1. III, p. 839.

2. Ibid., p. 861 .

3. duPont, Operation, Book 12, p. 21.

4. duPont, IN-6263, p. 185.

5. Ibid., p. 195.

6. HW-10475, Section C, p. 254.

7. History of Operations, OUT-1462, p. 46.

8. HW-10475, Section C.

9. duPont, Construction, Vol. III, Pp. 895-96; and HW-10475, Section C, p. 273.

10. duPont, Construction, Vol. III, pp. 910-911; and HW-10475, Section C, pp. 273, 526, 1108; and Helmholz, HW-31088; and Brunstad and Helmholz, HW-42111 RD; and Hauff, M-772 E-15; and Heffner, "Work Release...," December 14, 1950; and Lee, "Project Financial Closing Statement," September 27, 1951; and "Project Financial and Completion Report, Project M-757," June 27, 1951 .

11. duPont, Construction, HAN-10970, Volume III, pp. 913-914; and Pucher and Ingalls, HW-39871 RD; and Felt, ARH-2714; and Yoder and LaRiviere, SD-HS-SAR-003; and Brooks, SD-WM-SAR-0285. Al so see: Packer and Schmidt, HW-25396.

12. duPont, Construction, Vol. III, pp. 935-937; and HW-10475, Section C, pp. 268, 273; and Brands, "Work Release, Informal Request No. M-766;" and Heberer, "Construction Completion Notice, M-766."

13. duPont, Construction, Vol. III, pp. 961-963; and HW-10475, Section C, pp. 285-288.

14. duPont, Construction, Vol. III, p. 964; and HW-10475, Section C, p. A217; and Girdler, DUH-1072, pp. 1-3.

15. duPont, Operation, Book 12, p. 75.

16. Ibid., p. 76; and G.E. Hanford Co., "Property Disposal Report," \#54-217, May 23, 1954.

17. Ibid., p. 145 . 
18. Ibid., p. 174 .

19. Ibid., p. 179.

20. Ibid., p. 179.

21. Ibid., p. 180 .

22. duPont, Operation, Book 12, p. 49.

23. duPont, Operation, Book 14, pp. 168-169.

24. Greninger, HW-14110, pp. 13, 21, and 26; and G.E. Hanford Co., HDC-1770; and G.E. Hanford Co., HDC-2000-K.

25. duPont, Construction, Vo1. III, pp. 922-925; and HW-10475, Section C, pp. 908-914, 1108.

26. Waite, WHC-MR-0227; and Greninger, "Request for Informal Approval...," December 29, 1951; and Brands, "Work Release, Miscellaneous Work Order No. 009;" and Greninger, "Request for Approval...," August 7, 1952; and Healy, HW-28121; and Burns, HW-32716; and Coppinger and Smith, HW-33184; and Ludlow and Poucher, HW-33454; and Gile, HW-22081; and Haney and Honstead, HW-54599; and Bierschenck and McConiga, HW-51277.

27. Heid, HW-44784, p. 8, 42-44.

28. Jones, Manhattan, pp. 193-94, citing Minutes of the Conference at the Met Lab, October 15, 1942, in the Manhattan District Records, 1942-1946, National Archives and Records Center, Washington, DC; and Groves, Now, pp. 55-56, 69 .

29. duPont, Operation, Book 7, p. 87.

30. History of Operations, OUT-1462, p. 47.

31. duPont, IN-6263, pp. 196-197; and Smith, HW-18143, p. 25.

32. Matthias, "Journal and Notes," May 27, June 8, September 7, October 25, 1943 and January 24/25, February 21, 1944; and Church, et a1., "Report," pp. 49-53, 117a-117c; and duPont, Operation, Book. 12, p. 128.

33. Church, et al., "Report," pp. 20-22, 118-120; and duPont, Operation, Book 12, p. 128; and duPont, Construction, Vol. IV, pp. 1133-1138.

34. Church, et a1., "Report," pp. 48-53; and duPont, Operation, Book 12, pp. 128-30, 136-41, 158.

35. duPont, Operation, Book 12, p. 66, 158.

36. Ibid., pp. 66, 129. 
37. Dreher, HW-3-311-DEL; and Dreher, HW-3-3003 DEL.

38. Ibid., p. 65 .

39. Matthias, "Journal and Notes," February 20/21, February 26, March 1 , March 17, Apri1 20/21, May 3, May 9, May 18, June 1, June 8, July 4, July 6, July 10, July 30, August 5; and Crane, HW-7-1538; and Crane, HW-7-1672; and Clarke, in Lindblom, "Early Hanford Boss....," March 24, 1989.

40. duPont, Operation, Book 12, pp. 66-67.

41. duPont, Operation, Book 12, pp. 145, 157, 149, 195, and Book 7, p. 130; and Parker, HW-7-3005.

42. Roberts, HW-55569 RD, pp. 6-7; and Anderson, ARH-3026, p. 5; and Burger, L.L., PNL-7210-HEDR.

NOTE: According to revisions issued by the Hanford Environmental Dose Reconstruction Project's Technical Steering Panel in October 1992, the I-131 releases between 1944-1947 may have been higher by 70 percent. See Sivula, "Dose Panel Raises...," October 9, 1992; and Lobsenz, "Study Boosts Estimate...," October 15, 1992.

43. duPont, Operation, Book 7, pp. 49, 168.

44. Ibid., pp. 93-94.

NOTE: Sampling operations were resumed at the 292-T Building later in the 1940s, but the exact date is unknown.

45. Ibid., p. 121 .

46. Ibid., p. 159.

47. duPont, Operation, Book 7. pp. 49, 129-130, 165. Also see: Healy, $\mathrm{HW}-3-3495$; and Turner, HW-3-3603; and Turner, HW-3-5055; and Turner, HW-3-5402; and Turner, HW-3-5521.

48. See: Cantrill and Healy, HW-7-2604; and Parker, HW-7-3042; and Parker, $\mathrm{HW}-7-3217$; and Herde, HW-3-3455; and Herde, HW-3-3628; and Parker, DUH-12,744; and Healy, HW-7-4451.

49. Gamertsfelder, $\mathrm{HW}-7-5934$, p. 3 .

50. Gamertsfelder, C. C., 1947, Effects on Surrounding Areas Caused by the Operations of the H.E.W., HW-7-5934, p. 3, G.E. Hanford Company, Richland, Washington.

51. Herde, HW-08668; and Roberts, HW-55569-RD.

NOTE: The 1947 total I-131 emission may have been higher by 70 percent. See Sivula, "Dose Panel Raises...," Octuber 8, 1992; and Lobsenz, "Study Boosts Estimate...," October 15, 1992.

52. Thorburn, HW-07002; and Seymour, HW-07780, p. 1. 
53. Parker, HW-07920; and Adley, HW-09864; and MacCready, HW-07932. NOTE: The "water" scrubbers contained varying concentration of sodium hydroxide and sodium carbonate in solution.

54. Lawrence, HW-17829; and Parker, HW-08624; and Greager and MacCready, HW-08667; and Adley, HW-09864; and Healy, HW-15234; and Roberts, $\mathrm{HW}-55569 \mathrm{RD}$; and Herde and Cline, HW-14085.

55. Blasewitz, Carlisle, et al., HW-208476, Part I, pp. 12-13; and Work, HW-11529, pp. 7, 15-20; and Blasewitz, HW-18094; and Maider, HW-19032; and Bixler, "Permanent Installation of Humidity Equipment...," October 10, 1950; and Parker, HW-33068, pp. 1-2; and Wisehart and Adley, $\mathrm{HW}-28828$.

56. Windsheimer, HW-11374; and Wende, HW-13184; and Pike, "Letter to LeBaron," Aprit 5, 1950.

57. Parker, HW-09394; and Singlevich, HW-09871; and Gross, HW-09511; and Roberts, HW-55569 RD.

58. Warner, "Decontamination od Stack Gases," June 4, 1948; and Warner, "Stack Gas Problem Working Group - Meetings," August 20, 1948; and Stainken, HW-10956, pp. 1, 3.

59. Parker, HW-10568; and Thorburn, HW-18385; and Roberts, HW-55569 RD; and Jenne and Healy, HW-17381.

60. Schlemmer, GEH-26643, p. 1; and Steele, "In 1949 Study, Hanford Allowed...," March 6, 1986, citing K. Price; and 0'Toole, "Hanford Tests...," April 10, 1986, citing M. Lawrence; and Heinz, "Emission at Hanford...," May 13, 1988, citing C. Gamertsfelder; Briggs, "Military Blocked Delay...," May 6, 1989, citing C. Gamertsfelder; and U.S. General Accounting Office, GAO/RCED-94-5IFS, p. 9; and Jenne and Healy, HW-17381.

61. Jenne and Healy, HW-17381; and Paas and Singlevich, HW-17003; and Schlemmer, GEH-26643, p. 1 .

62. Steele, "In 1949 Study, Hanford Allowed...," March 6, 1986; and 0'Toole, "Hanford Tests...," April 10, 1986; and Associated Press, "Report Details 2nd...," December 25, 1987; and Heinz, "Emission at Hanford...," May 13, 1988; and Whitney," '49 Iodine Releases Larger...." May 4, 1989; and Briggs, "Military Blocked Delay...," May 6, 1989; and Sivula, "Declassified Report...," August 28, 1992.

63. Blasewitz, HW-15367; and Work, HW-19898; and Parker, 18409; and Szulinski, HW-19609; and Brands, "Work Release, Project C-378...," May 23, 1950; and Jessen, "Project Physical Completion Notice," September 24, 1951; and Cooper, HW-20757; and Paas and Soldat, HW-21891.

64. Work, HW-19898; and Blasewitz, Carlisle, et al., HW-20332; and Szulinski, HW-19609; and Parker, HW-18567; and Kirkendall, HW-21426; and Paas and Soldat, HW-21891; and Parker, HW-21511; and McAdams, HW-21905; and Blasewitz, HW-21631; and Blasewitz and Judson, HW-21826; and Soule and Taylor, HW-27580. 
WHC-MR-0452, ADDENDUM 1

NOTE: The T Plant production test with mercury demonstrated some success, and mercury began to be used as a regular additive to dissolver solutions to help suppress I-131 evolution.

65. Parker, HW-18409; and Roberts, HW-55569 RD; and Mickelson, HW-21699, pp. 4, 40, 48; and Paas and Soldat, HW-2189l; and Parker, HW-20866; and Parker, HW-22576.

66. Blasewitz, HW-21957; and Blasewitz and Judson, HW-21826; and Soule and Taylor, HW-27580; and Browne, HW-36112; and Gross, "Request for Informal Approva1...," August 27, 1952; and Lee, "Projects," May 25, 1953; and Peters, "Unitization Report...," June 9, 1953; and Bailor, HW-26547; and Browne, "I-131 Emission --. T Plant," March 4, 1955; and Vanderbeek, HW-36563; and Amos, HW-41053; and Roberts, HW-55569 RD; and Helgeson, $\mathrm{HW}-44879$; and $\mathrm{Hill}$, et a1., HW-39073.

67. G.E. Hanford Co., HW-22201-DEL, pp. 7, 22-23.

68. G.E. Hanford Co., HW-26705-DEL, Pp. 8, 14; and S Division, "Request for Appropriation M-606;" and Brands, "Work Release, Suspense No. M-606;" and Campbe11, "Project Unitization Report, Project M-606;" and Mobley, HW-19716; and Browne, HW-31182; and Browne, HW-31989; and Schmidt, HW-34253; and Schmidt, HW-35055. Al so see: Browne, HW-32875.

69. G.E. Hanford Co., HW-30000-DEL, p. 23.

70. G.E. Hanford Co., HW-34000-OEL, pp. 17, 19-20; and Felts, HW-33093-RD.

71. G.E. Hanford Co., HW-39900-DEL, pp. 3, 20; and Johnson, HW-33048.

72. G.E. Hanford Co., HW-50000-DEL, Pp. 23-25; and G.E. Hanford Co., "Monthly Report...," HW-42219, pp. E-2 and Ed-1.

73. duPont, HAN-73214, Book 7, pp. 90, 92, 120,156-57, 159; and Investigating Committee, "Special Hazards Incident Investigation 222-T \#8;" and U.S. DOE, DOE/AD-0015, p. 2-127.

74. Tabb, "Special Hazards Incident Investigation, Incident 68, Class I," December 4, 1947; and Maider, HW-19032, p. 3; and Keene, "Special Hazards Incident Investigation No. 116, Class I, "May 17, 1949; and Ebright, "Special Hazards Incident Investigation \#32," April 17, 1951; and Hewitt, HW-28774; and Ebright, W-28125; and Foskett, "Follow-up on Radiation Incident Investigation, Class I Number 49," February 20, 1953; and Corley, HW-28001; and Hewett, HW-28415.

75. Lindberg, B. G., HW-28707; and Corley, HW-28680.

76. Lindberg, HW-31138; and Corley, HW-31517-DEL; and Lindberg, HW-30112; and Donelson, HW-30372; and Lindberg, HW-30650; and Ebright, HW-30696-DEL.

77. Donel son, HW-35540-DEL; and Wilson, HW-36034-AD; and U.S. DOE, DOE/AD-0015, p. 2-11; and Corley, HW-35575; and Vanderbeek, HW-41074; and Backman, HW-40765; and Jordan, "Radiation Occurrence No. 7," September 7, 
1960; and Short, "Radiation Occurrence No. 8," October 3, 1960; and Research Department, ARH-2874.

78. G.E. Hanford Co., "Monthly Report...," HW-42219, p. E-2; and Kane, HW-56193; and Kingsley and Short, HW-63110; and Szul inski, ARH-SA-181, p. 1; and G.E.. Hanford Co., Property Disposal Requests CPD 57-41, 64-274, $179-59,182-59,49-60,164-60,167-60,175-60,173-61,8-62,12-62$, $14-62,165-62,69-63,83-63,64-187,64-249,64-274,65-5,65-70,65-121$, $66-116,66-125$; and Project Records, CAC-812. See also: Hughes, $H W-38052$.

79. G.E. Hanford Co., Property Disposal Requests 63-150, 64-78, 64-189.

80. G.E. Hanford Co., Property Disposal Request 64-188.

81. G.E. Hanford Co., Property Disposal Request 66-37.

82. Isochem, inc., Property Disposal Requests 67-183, 67-184, 67-209, 68-21; and Atlantic Richfield Hanford Co., Property Disposal Requests 68-28, 69-172.

83. Kingsley and Short, HW-63110; and G.E. Hanford Co., HW-63703; and Ayers, BNWL-B-90; and Szulinski, ARH-SA-181; and Koontz, RHO Internal Letter RLK-72900-640-82.

84. Kingsley and Short, HW-63110, pp. 16-17; and Wiater, "Monthly Equipment Progress Reports" January - December 1969.

85. Kienzle, H. F., RHO-CD-1311, Section I; and Wiater, ISO-915; and Howe and Marsh, RHO Internal Memo 72320-82-309; and Wojtasek, HO Internal Memo, 65410-82-136; and Emerick, RHO Internal Memo "TMI Preparation," 1982; and Howe and Marsh, RHO Internal memo 72320-82-318; and Bates, Colvin and Rutz, "Environmental Evaluation," 1982; and Patterson, RHO Internal memo 46000-83-035.

86. Ewalt, et al., "Report of the Investigation...," December 7, 1990; and Hamilton, "Operations at T-Plant Complex," January 9, 1991; and Doyle and Bottenus, RL-WHC-TPLANT-1990-0172. Also see: Cruz, et al., WHC-SA-1979-FP.

87. Doyle, RL-WHC-TPLANT-1991-0057; and Wagoner, "Award Fee Determination...," June 7, 1991. Also see: Cruz, et al., WHC-SA-979-FP.

88. Felton, "The ' $T$ ' Now Means 'Teamwork, " July 15, 1991; and Felton, "T-Plant Board of Directors...," August 26, 1991; and Faulk, WHC Internal Memo 87400-92-GWF-017.

89. "Plant Activities Support Mission," January 4, 1993; and McGuire, WHC Correspondence \#9257569.

90. Schwartz, SD-SQA-CSA-20104 (CSAR 86-007); and Friar, WHC-SD-SQA-CSA-20153; and Semmens, WHC-SD-CP-SAR-007, Rev. 1; and Ortega, OSD-D-187-00008, B-0; and Hanson and Jackson, RHO-CD-356; and MCClelland, RHO-CD-423, Rev. 1 . 
91. Bottenus, RL-WHC-TPLANT-1991-1028.

92. Metzger, RL-WHC-TPLANT-1991-1021; and Westinghouse Hanford Co., Project $\mathrm{C}-134$.

93. Roberts, RL-WHC-TPLANT-1991-1011; and Metzger, RL-WHC-TPLANT-1992-0019; and McKenney, "T-Plant Meets...," April 12, 1993.

94. U.S. Department of Energy, DOE/RL-93-70, Rev. 1; and Westinghouse Hanford Co., "Hanford Facility Dangerous Waste Part A Permit Application, Revision 1, for the T-Plant Complex," September 1993; and Harrison, PCHB-93-64.

95. Hamilton, "Operations at the T-Plant Complex," February 4, 1993; and Norton, "Completion of 2706-T Operational Readiness Review"; and Hunter, "Department of Energy Approval of Limited Restart of Operations in 2706-T;" and Roe, "Hanford's Mission Helps 0ld Facility Get New Lift," August 2, 1993.

96. Kurts, "New T-Plant Sampling Method...," July 26, 1993; and Semmons, WHC-SD-CP-SAR-007, Rev. 1, Table 5-1. Also see Bottenus, RL-WHC-TPLANT-1991-0104; and Bottenus, RL-WHC-TPLANT-1991-1001.

97. Bottenus, RL-WHC-TPLANT-1993-0052.

98. Westinghouse Hanford Co., WHC-FYWP-1993-WDS; and Westinghouse Hanford Co., "Change Request SWD-93-58."

99. Westinghouse Hanford Co., WHC-SP-1030. 
WHC-MR-0452, ADDENDUM 1

This page intentionally left blank. 


\subsection{BIBLIOGRAPHY}

The documents listed in this bibliography represent references found in this document and WHC-MR-0452, Dramatic Change at $T$ Plant.

Adley, F. E., 1948, Report of a Study of the Fate of 200 Area Stack Gases, HW-09864, G.E. Hanford Company, Richland, Washington.

Amos, L. C., 1955, Regeneration of Silver Reactors, HW-41053, G.E. Hanford Company, Richland, Washington.

Anderson, J. D., 1974, Emitted and Decayed Values of Radionuclides in Gaseous Wastes Discharged to Atmosphere, ARH-3026, Atlantic Richfield Hanford Company, Richland, Washington.

ARHCO, 1968-1969, "Property Disposal Requests," (various), Atlantic Richfield Hanford Company, Richland, Washington.

ARHC0, 1973, 241-T-106 Tank Leak Investigation, ARH-2874, Research Department, Atlantic Richfield Hanford Company, Richland, Washington.

Associated Press, 1987, "Report Details 2nd Radiation Release at Hanford," Tri-City Herald, p. Bl, Kennewick, Washington.

Ayers, J. A., 1971, Equipment Decontamination with Special Attention to Solid Waste Treatment - Survey Report, BNWL-B-90, Battelle Northwest Laboratories, Richland, Washington.

Backman, G. E., 1956, Manufacturing Department, Radiation Incident Investigation, Class I, \#553-C, HW-40765, G.E. Hanford Company, Richland, Washington.

Bailor, W. C., 1952, Authorization for Change in Operating Standards 221 and 224 Buildings, HW-26457, G.E. Hanford Company, Richland, Washington.

Bates, J. A., C. A. Colvin, and A. C. Rutz, 1982, Environmental Evaluation Receipt, Handling and Burial of TMI Submerged Demineralizer System Liners at Hanford, Rockwell Hanford Operations, Richland, Washington.

Bierschenck, W. H., and M. W. McConiga, 1957, Changes in the Hanford Water Table, 1944-1957, HW-51277, G.E. Hanford Company, Richland, Washington.

Bixler, R. B., 1950, Permanent Installation of Humidity Equipment for Canyon Ventilation Air in Passage Through Sand Filter, G.E. Hanford Company, Richl and, Washington.

Blasewitz, A. G., 1949, Iodine Evolution During Metal Dissolution, HW-15367, G.E. Hanford Company, Richland, Washington.

Blasewitz, A. G., R. V. Carlisle, B. F. Judson, M. F. Katzer, E. F. Kurtz, W. C. Schmidt, and B. Weidenbaum, 1951, Decontamination of Dissolver Vent Gases at Hanford, HW-20332, G.E. Hanford Company, Richl and, Washington. 
Blasewitz, A. G., R. V. Carlisle, B. F. Judson, M. F. Katzer, E. F. Kurtz, W. C. Schmidt, and B. Weidenbaum, 1951, Filtration of Radioactive Aerosols by Glass Fibers, HW-20847, G.E. Hanford Company, Richland, Washington.

Blasewitz, A. G., 1951, I-131 Content of Plant Silver Reactors, HW-21631, G.E. Hanford Company, Richland, Washington.

Blasewitz, A. G., 1951, Performance of Replacement and Regenerated Silver Reactors - Operated at 375 Degrees, HW-21957, G.E. Hanford Company, Richland, Washington.

B1asewitz, A. G., and B. F. Judson, 1951, Variation in Silver Reactor Performance, HW-21826, G.E. Hanford Company, Richland, Washington.

Bottenus, R. J., 1992, Off-Normal Report: Administrative Controls Relative to Monitoring PWR Fuel Pool Level Indication, RL-WHC-TPLANT-1991-1028, Westinghouse Hanford Company, Richland, Washington.

Bottenus, R. J., 1992, Off-Normal Report: Violation of Permit Condition for More Than 90 Day Accumulation, RL-WHC-TPLANT-1991-1001, Westinghouse Hanford Company, Richland, Washington.

Bottenus, R. J., 1992, Unusual Occurrence Report: Violation of Limiting Control Setting - Tank 5-7, RL-WHC-TPLANT-1991-0104, Westinghouse Hanford Company, Richland, Washington.

Bottenus, R. J., 1993, Unusual Occurrence Report: Limited Access to T-Plant Canyon Due to Potential Alpha Contamination, RL-WHC-TPLANT-1993-0052, 10-Day Report, Westinghouse Hanford Company, Richland, Washington.

Brands, J. W., 1950, Work Release, Informal Request No. M-766: Installation of Laboratory Furniture in Buildings 271 T\&B, G.E. Hanford Company, Richland, Washington.

Brands, J. W., 1950, Work Release, Project C-378: Iodine Removal Facilities for Dissolver Off-Gas, and Addendums 1, 2, and 3 (1951), G.E. Hanford Company, Richland, Washington.

Brands, J. W., 1951, Work Release, Informal Approval No., M-772: Improved Decontamination Facilities - Buildings 222 T\&B: Addendum No. 2, G.E. Hanford Company, Richland, Washington.

Brands, J. W., 1951, Work Release, Suspense No. M-606: Underwater Repair Facilities $221 T$ \& B, G.E. Hanford Company, Richland, Washington.

Brands, J. W., 1952, Work Release: Miscellaneous Work Item No. 009: 224 Waste Diversions, 200-West Area, G.E. Hanford Company, Richland, Washington.

Briggs, W., "Military Blocked Delay of Green Run," Tri-City Herald, May 6, 1989, p. Al, Richland, Washington. 
Brooks, W. E., 1987, Transuranic Waste Storage and Assay Facility, Hazards Identification and Evaluation, SD-WM-SAR-0285, Westinghouse Hanford Company, Richland, Washington.

Browne, W. G., 1954, 215 MWD/TON Batch Size Limits and Control in the Bismuth Phosphate Plant, HW-31989, G.E. Hanford Company, Richland, Washington.

Browne, W. G., 1954, Bi smuth Phosphate Process Under 215 MWD Program, HW-31182, G.E. Hanford Company, Richland, Washington.

Browne, W. G., 1954, Essential Material Flow Sheet of Precipitation Separations Process, HW-32875, G.E. Hanford Company, Richland, Washington.

Browne, W. G., and H. P. Maffei, 1955, I-131 Control by Two Silver Reactor Units in Series, HW-39485, G.E. Hanford Company, Richland, Washington.

Browne, W. G., 1955, I-131 Emission Problem - Bismuth Phosphate Plant, HW-36112, G.E. Hanford Company, Richland, Washington.

Browne, W. G., "I-131 Emission -- T Plant," (memo to C. T. Groswith, dated March 4, 1955), G.E. Hanford Company, Richland, Washington.

Brunstad, A., and H. R. Helmholz, 1956, Counting Methods and Calculations Used by the Analytical Laboratories - Separations Section, HW-42111, G.E. Hanford Company, Richland, Washington.

Burger, L. L., 1991, Fission product Iodine During Early Hanford-Site Operations: Its Production and Behavior During Fuel Processing, off-Gas Treatment and Release to the Atmosphere, PNL-7210-HEDR, Pacific Northwest Laboratory, Richland, Washington.

Burns, R. E., 1954, Decontamination of Bismuth Phosphate Process First Cycle and Coating Removal Wastes, HW-32716, G.E. Hanford Company, Richland, Washington.

Campbe11, K. K., 1952, Project Unitization Report, Project M-606, G.E. Hanford Company, Richland, Washington.

Cantrill, S., and J. W. Healy, 1945, Iodine Metabolism with Reference to I-131, HW-7-2604, Hanford Engineer Works, Richland, Washington.

Church, P. E., C. A. Gosline, 0. H. Newton, J. F. Mattingly, and L. F. Morkus, 1944, Report of the Meteorology Section, From January 1943 to July 1944, Hanford Engineer Works, Richland, Washington.

Cooper, V. B., 1951, Modification of Off-Gas Filters, HW-20757, G.E. Hanford Company, Richland, Washington.

Coppinger, E. A., and R. E. Smith, 1954, BiPO $\mathrm{Pl}_{4}$ ane Nickel Ferrocyanide Scavenging Flowsheet for First-Cycle Waste Containing no Coating-Removal Waste, W-33184, G.E. Hanford Company, Richland, Washington. 
Corley, J. P., 1953, Manufacturing Department, Radiation Incident Investigation, Class I, Incident Number 67, HW-28001, G.E. Hanford Company, Richiand, Washington.

Corley, J. P., 1953, Manufacturing Department, Radiation Incident Investigation, Class I, 74, HW-28680, G.E. Hanford Company, Richland, Washington.

Corley, J. P., 1954, Manufacturing Department, Radiation Incident Investigation, Class I, 354, HW-31517-DEL, G.E. Hanford Company, Richl and, Washington.

Corley, J. P., 1955, Manufacturing Department, Radiation Incident Investigation, Class I, 422, HW-35575, G.E. Hanford Company, Richl and, Washington.

Crane, P. W., 1945, Processing Histury on Production Batches, HW-7-1538, Hanford Engineer Works, Richland, Washington.

Crane, P. W., 1945, Processing History of Production Batches, HW-7-1642, Hanford Engineer Works, Richland, Washington.

Cruz, E. A., R. M. Millikin, and C. E. Wills, 1993, Upgrading a 1944 Plutonium-Extraction Plant to a Modern Decontamination Facility, WHC-SA-1979-FP, Westinghouse Hanford Company, Richland, Washington.

DOE, 1991, Hanford Process Review, DOE/AD-0015, U.S. Department of Energy, Washington, D.C.

DOE, 1993, Waste Analysis Plan for Confirmation or Completion of Tank Farms Backlog Waste Designation, DOE/RL-93-70, Rev. 1, U.S. Department of Energy, Richland Operations Office, Richland, Washington.

Donel son, R. N., 1953, Manufacturing Department, Radiation Incident Investigation, Class I, \#94, HW-30372, G.E. Hanford Company, Richland, Washington.

Donelson, R. N., 1955, Manufacturing Department, Radiation Incident Investigation, Class $I, \# 425$, HW-35540-DEL, G.E. Hanford Company, Richl and, Washington.

Doyle, R. M., and R. J. Bottenus, 1991, Unusual 0ccurrence Report: Disabling Remote CAM Alarm Annunciator, RL-WHC-TPLANT-1990-0172, Westinghouse Hanford Company, Richland, Washington.

Doyle, R. M., 1991, Unusual Occurrence Report: Limited Decontamination operation, RL-WHC-TPLANT-1991-0057, Westinghouse Hanford Company, Richland, Washington.

Dreher, J. L., 1944, Wind Dilution Required to Reduce to Tolerance Levels the Activity Due to Xenon and Iodine in H.E.W. Dissolver off-Gases, HA-3-311-DEL, Hanford Engineer Works, Richland, Washington. 
Dreher, J. L., 1945, Memorandum Report - SE-PC-\#74: The Evolution of Iodine During Metal Dissolution, HW-3-3003-DEL, Hanford Engineer Works, Richland, Washington.

duPont, 1945, Design and Procurement History of Hanford Engineer Work and Clinton Semi-Works, IN-6263, E. I. duPont de Nemours and Company, Wilmington, Delaware.

duPont, 1946, Construction of Hanford Engineer Works: History of the Project, HAN-10970, Volume III, E. I. duPont de Nemours and Company, Wilmington, Del aware.

duPont, 1946, Operation of Hanford Engineer Works: History of the Project, HAN-73214, Books 7, 12, and 14, E. I. duPont de Nemours and Company, Wilmington, Delaware.

"duPont Out - GE In!," Richland Villager, Extra, June 6, 1946, Richland, Washington.

Ebright, D. P., 1951, "Special Hazards Incident Investigation," Incident 32, G.E. Hanford Company, Richland, Washington.

Ebright, D. P., 1953, Radiological Sciences Department Investigation, Radiation Incident, Class I, No. 272, HW-28125, G.E. Hanford Company, Richland, Washington.

Ebright, D. P., 1954, Radiological Sciences Department Investigation, Radiation Incident, Class I, No. 366, HW-30596-DEL, G.E. Hanford Company, Richland, Washington.

Emerick, S. K., "TMI Preparation," Internal Memo, dated September 3, 1982, Rockwell Hanford Operations, Richland, Washington.

Ewalt, J. R., R. A. Fell, J. R. Knight, D. A. Lawrence, and J. C. Midgett, 1990, Report of the Investigation of the Disabling of Continuous Air Monitor Alarm at T-Plant, Final Draft, Westinghouse Hanford Company, Richland, Washington.

Faulk, G. W., "Decontamination Task Force," WHC Internal Memo 87400-92-GWF-017, dated February 12, 1992, Westinghouse Hanford Company, Richland, Washington.

Felt, R. E., 1973, Criticality Safety Analysis Report Storage of Pu in 224-Building, ARH-2714, Atlantic Richfield Hanford Company, Richland, Washington.

Felton, G., "The 'T' Now Means 'Teamwork', "Hanford Reach, dated July 15, 1991, p. 5, Westinghouse Hanford Company, Richland, Washington.

Felton, G., "T-Plant Board of Directors Meets for First Time," Hanford Reach, dated August 26, 1991, Westinghouse Hanford Company,

Richland, Washington. 
Felts, W. R., 1954, Design Criteria - Part I: "B" Plant Reactivation 4X Program, HW-33093-RD, G.E. Hanford Company, Richland, Washington.

Foskett, E. A., "Follow-Up on Radiation Incident Investigation, Class I, Number 49," (memo to V. R. Chapman, dated February 20, 1953), G.E. Hanford Company, Richland, Washington.

Foster, C. B., and M. J. Szulinski, 1974, Decontamination of Obsolete Processing Facilities at Hanford, ARH-SA-183, Atlantic Richfield Hanford Company, Richland, Washington.

Friar, D. E., 1990, PWR Core 2 Blanket Fuel Storage Cell 4, 221-T Building, WHC-SD-SQA-CSA-20153, Westinghouse Hanford Company, Richl and, Washington.

Gamertsfelder, C. C., 1947, Effects on Surrounding Areas Caused by the Operations of the H.E.W., HW-7-5934, G.E. Hanford Company, Richland, Washington.

GAO, 1994, Nuclear Health and Safety: Examples of Post World War II Radiation Releases at U.S. Nuclear Sites, GAO/RCED-94-51FS, U.S. General Accounting Office, Washington, D.C.

G.E., 1950, Completion Report: Design and Construction of RALA Facility Project C-343, HDC-1770, G.E. Hanford Company, Richland, Washington.

G.E., 1951, Four Years at Hanford, HW-22201-DEL, G.E. Hanford Company, Richland, Washington.

G.E., 1951, Project C-343: Design and Construction of a RALA Facility, HDC-2000-K, G.E. Hanford Company, Richland, Washington.

G.E., 1953, 1952 at Hanford Works, HW-26705-DEL, G.E. Hanford Company, Richland, Washington.

G.E., 1954, 1953 at Hanford, HW-30000-DEL, G.E. Hanford Company, Richland, Washington.

G.E., 1955, 1954 at Hanford, HW-34000-DEL, G.E. Hanford Company, Richland, Washington.

G.E., 1956, 1955 at Hanford, HW-39900-DEL, G.E. Hanford Company, Richland, Washington.

G.E., 1956, Monthly Report, Hanford Atomic Products Operation for March 1956 , HW-42219, G.E. Hanford Company, Richland, Washington.

G.E., 1957, 1956...Annual Report...1956, HW-50000-DEL, G.E. Hanford Company, Richland, Washington.

G.E., 1960, Disposition of Contaminated Processing Equipment at Hanford Atomic Products Operation, 1958-1959, HW-63703, G.E. Hanford Company, Richland, Washington. 
G.E., "Project Records for Project CAC-812: Equipment Decontamination Building 2706-W," 1958-1959, G.E. Hanford Company, Richland, Washington.

G.E., "Property Disposal Reports/Requests," (various), 1954-1965, G.E. Hanford Company, Richland, Washington.

Gile, H. S., 1951, Proposed Combination of Neutralized Concentration Building Wastes with Neutralized 5-6 and Second Cycle Wastes, HW-22081, G.E. Hanford Company, Richland, Washington.

Girdler, R. M., 1944, Building 291 - Stack Activity, Hanford Section, DUH-1072, E. I. duPont de Nemours and Company, Wilmington, Delaware.

Greager, 0. H., and W. K. MacCready, 1948, Stack Gas Decontamination Separations Plant, HW-08667, G.E. Hanford Company, Richland, Washington.

Greninger, A. B., 1949, Proposal for Laboratory Facilities in the Technical Center, HW-14110, G.E. Hanford Company, Richland, Washington.

Greninger, A. B., "Request for Informal Approval 224 Waste Diversions - 200 East and West Areas," (letter to D. F. Shaw, dated December 29, 1951), G.E. Hanford Company, Richland, Washington.

Greninger, A. B., "Request for Approval of Revision of Informal Request No. 112: 224 Waste Diversions, 200 East and West Areas," (letter to D. F. Shaw, dated August 7, 1952), G.E. Hanford Company, Richland, Washington.

Gross, C. N., 1948, Increases of Decay Time for Irradiated Metal, HW-09511, G.E. Hanford Company, Richland, Washington.

Gross, C. N., "Request for Informal Approval "T" Plant Process Ventilation Improvements," (letter to D. F. Shaw, dated August 27, 1952), G.E. Hanford Company, Richland, Washington.

Groves, L. R., 1942, Now It Can Be Told: The Story of the Manhattan Project, Harper and Brothers, New York.

Hamilton, W. H., Jr., "Operations at T-Plant Complex," (memo to R. J. Cash, et al., dated January 9, 1991), Westinghouse Hanford Company, Richland, Washington.

Hamilton, W. H., Jr., "Operations at the T-Plant Complex," (memo to H. E. McGuire, dated February 4, 1993), Westinghouse Hanford Company, Richland, Washington.

Haney, W. A., and J. F. Honstead, 1958, A History and Discussion of Specific Retention Disposal of Radioactive Liquid Wastes in the 200 Areas, HW-54599, G.E. Hanford Company, Richland, Washington.

HEW, 1944, Hanford Technical Manual, Section C, HW-10475-C, Hanford Engineer Works, Richland, Washington. 
HEW, 1945, History of Operations (1 January 1944 to 20 March 1945), OUT-1462, Hanford Engineer Works, Richland, Washington.

Hanson, G. L., and R. R. Jackson, 1978, Safety Assessment Document - PWR Core 2 Project, RHO-CD-356, Rockwell Hanford Operations, Richland, Washington.

Harrison, W. A., 1993, "Settlement Agreement and Order Thereon," PCHB 93-64, Pollution Control Hearings Board, Lacey, Washington.

Hauff, T. W., 1950, Improved Decontamination Facilities - Building 222 T\&B, M-772 E-15, G.E. Hanford Company, Richland, Washington.

Healy, J. W., 1946, Detection of I-131 in the Body, HW-7-4451, Hanford Engineer Works, Richland, Washington.

Healy, J. W., 1946, Vegetation Contamination for First Quarter of 1946, HW-3-3495, Hanford Engineer Works, Richland, Washington.

Healy, J. W., 1949, Your Reference GMI, HW-15234, G.E. Hanford Company, Richland, Washington.

Healy, J. W., 1953, Release of Radioactive Wastes to Ground, HW-28121, G.E. Hanford Company, Richland, Washington.

Heberer, J. F., 1950, Construction Completion Notice, Project No. M-766, G.E. Hanford Company, Richland, Washington.

Hedengren, D. C., "T-Plant Impact on the Decontamination and Repair (D\&R) Program Life Cycle Cost," (WHC Internal Memo 65470-87-114, dated September 23, 1987), Westinghouse Hanford Company, Richland, Washington.

Heffner, J. M., 1950, Work Release, Informal Approval No., M-772: Improved Decontamination facilities - Building $222 T \& B$, (and J. W. Brands, Addendum No. 2, May 28, 1951), G.E. Hanford Company, Richland, Washington.

Heid, K. R., 1956, Radioactive Contamination in Liquid Wastes Discharged to Ground at Separations Facilities Through June 1956, HW-44784, G.E. Hanford Company, Richland, Washington.

Heinz, S., "Emission at Hanford Part of Cold War," Oregonian, dated May 13, 1988, p. B2, Portland, Oregon.

Helgeson, G. L., 1956, T-Plant Iodine Study - Final Report, HW-44879, G.E. Hanford Company, Richland, Washington.

Helmholz, H. R., 1954, Determination of Sr-90, Sb-125, Cs-137, and Absolute Beta Activities in First Cycle Supernatant, HW-31088, G.E. Hanford Company, Richland, Washington.

Herde, K. E., 1945, I-131 Deposition in Cattle Grazing on North Margin of H.E.W., HW-3-3628, Hanford Engineer Works, Richland, Washington. 
Herde, K. E., 1946, I-131 Accumulation in the Thyroid of Sheep Grazing Near H.E.W., HW-3-3455, Hanford Engineer Works, Richland, Washington.

Herde, K. E., 1948, Radioactivity in Upland Wild-Fowl from Areas Surrounding the Hanford Works Project, HW-08668, G.E. Hanford Company, Richland, Washington.

Herde, K. E., and J. F. Cline, 1949, Biological Monitoring of Separation Plant Areas By Use of Native and Domestic Rabbits, HW-14085, G.E. Hanford Company, Richland, Washington.

Hewett, L. H., 1953, Radiological Sciences Department Investigation, Radiation Incident, Class I, No. 284, HW-28415, G.E. Hanford Company, Richland, Washington.

Hewett, L. H., 1953, Radiological Sciences Department Investigation, Radiation Incident, Class I, No. 250, HW-28774, G.E. Hanford Company, Richland, Washington.

Hewlett, R. G., and F. Duncan, 1972, Atomic Shield: A History of the United States Atomic Energy Commission, WASH-1215, U.S. Atomic Energy Commission, Washington, D.C.

Hi11, C. F., et al., 1955, Symposium on Iodine Problem, HW-39073, G.E. Hanford Company, Richland, Washington.

Hollenbach, F. A., 1949, A Study of Proposed Semi-Parallel and Complete Paraliel Operations of the Canyon and Concentration Buildings 200 Areas, HW-12730, G.E. Hanford Company, Richland, Washington.

Howe, D. B., and D. A. Marsh, "Inspection of T-Plant Crane Cab and Canyon for TMI-II SDS Liner Transloading," (Internal Memo 72320-82-309, dated August 31, 1982), Rockwell Hanford Operations, Richland, Washington.

Howe, D. B., and D. A. Marsh, "CAM Coverage for 221-T Railroad Tunnel During TMI-SDS Liner Transloading," (Internal Memo 72320-82-318, dated September 7, 1982), Rockwell Hanford Operations, Richland, Washington.

Hughes, H. R., 1955, Contaminated Equipment Renovation Shop: A Preliminary Study, HW-38052, G.E. Hanford Company, Richland, Washington.

Hunter, J. R., "Department of Energy Approval of Limited Restart of Operations in 2706-T," (Letter to President, WHC, dated November 1993), U.S. Department of Energy, Richland, Washington.

Isochem, "Property Disposal Requests," (various), dated 1966-1967, Isochem, Inc., Richland, Washington.

Jenne, D. E., and J. W. Healy, 1950, Dissolving of Twenty Day Metal at Hanford, HW-17381, G.E. Hanford Company, Richland, Washington.

Jessen, R. T., 1951, "Project Physical Completion Notice: Project C-378," G.E. Hanford Company, Richland, Washington. 
Johnson, H. G., 1954, TBX Plant Study, HW-33048, G.E. Hanford Company, Richland, Washington.

Jones, V. C., 1985, Manhattan: The Army and the Bomb, U.S. Center for Military History, Washington, D.C.

Jordan, J. W., 1960, Radiation Occurrence No. 7, G.E. Hanford Company, Richland, Washington.

Kane, J. F., 1958, Scope Study: Proposed Centralized Decontamination Facility, HW-56193, G.E. Hanford Company, Richland, Washington.

Keene, A. R., 1949, Special Hazards Incident Investigation No. 116, Class I, G.E. Hanford Company, Richland, Washington.

Kienzle, H. F., 1980, Multi-Purpose Transfer Box, RHO-CD-1311, Rockwell Hanford Operation, Richland, Washington.

Kingsley, P. S., and M. L. Short, 1960, Decontamination, HW-63110, G.E. Hanford Company, Richland, Washington.

Kirkenda11, B. E., 1951, Production Test 221-T-15: Control of Radio-Iodine in Canyon Building Exhaust Ventilation Air, HW-21426, G.E. Hanford Company, Richland, Washington.

Koontz, R. L., "291-T-1: Upgrade for Three Mile Island (TMI) (Telephone Conversation with G.F. Boothe," (Internal Letter RLK-72900-640-82, dated September 15, 1982, Rockwell Hanford Operations, Richland, Washington.

Kurts, M. E., "New T-Plant Sampling Method Reduces Worker Exposure," Hanford Reach, July 26, 1993, p. 5 , Westinghouse Hanford Company, Richland, Washington.

Lawrence, S. J., 1948, Program for Obtaining Design Data from a 6" Bubble Cap Column for Removal of Radioiodine from the Stack Gases, HW-17829, G.E. Hanford Company, Richland, Washington.

Lee, J.F., 1951, 1951, "Project Financial Closing Statement, Project No. M-772," G.E. Hanford Company, Richland, Washington.

Lee, J. F., "Projects," (Memo to C. P. Cabell, dated May 25, 1953), G.E. Hanford Company, Richland, Washington.

Lindberg, B. G., 1953, Radiological Sciences Department Investigation, Radiation Incident, Class I, No. 249, HW-30112, G.E. Hanford Company, Richland, Washington.

Lindberg, B. G., 1953, Radiological Sciences Department Investigation, Radiation Incident, Class I, No. 295, HW-28707, G.E. Hanford Company. Richland, Washington.

Lindberg, B. G., 1954, Radiological Sciences Department Investigation, Radiation Incident, Class I, No. 327, HW-30650, G.E. Hanford Company, Richland, Washington. 
Lindberg, B. G., 1954, Radiological Sciences Department Investigation, Radiation Incident, Class I, No. 349, HW-31138, G.E. Hanford Company, Richland, Washington.

Lindblom, M., "Early Hanford Boss Makes Nostalgic Visit," Tri-City Herald, March 24, 1989, p. A3, Richland, Washington.

Lobsenz, G., "Study Boosts Estimate of Hanford Releases," Energy Daily, Vo1. 20, p. 199, October 15, 1992, Richland, Washington.

Ludlow, J. 0., and F. W. Poucher, 1954, T-Plant First Cycle Waste Scavenging, HW-33454, G.E. Hanford Company, Richland, Washington.

MacCready, W. K., 1947, Installation of Air Filters - 200 Areas, HW-07932, G.E. Hanford Company, Richland, Washington.

Maider, J. E., 1950, Operations Incidents, HW-19032, G.E. Hanford Company, Richland, Washington.

Matthias, F. T., "Journal and Notes," (Personal journal notes, 1943-1945), U.S. Department of Energy Public Reading Room, Richland, Washington.

McAdams, W. A., 1951, H.I. Division Monthly Report on 200 Areas and Associated Labs for Month of July 1951, HW-21905, G.E. Hanford Company, Richland, Washington.

McClelland, B. C., 1978, PWR Core 2 - Operations Safety Requirements, RHO-CD-423, Rev.1, Rockwell Hanford Operations, Richland, Washington.

McGuire, H. E., "Decontamination Task Team Recommendations," (WHC Correspondence \#9257569, dated October 21, 1992), Westinghouse Hanford Company, Richland, Washington.

McKenney, D. E., "T-Plant Meets Non-Compliance Issue With Enthusiasm, Dedication," Hanford Reach, April 12, 1993, p. 5, Westinghouse Hanford Company, Richland, Washington.

Metzger, S. L., 1991, Off-Normal Report: Radiological Characterization of the T-Plant Complex, RL-WHC-TPLANT-1991-1021, Westinghouse Hanford Company, Richland, Washington.

Metzger, S. L., 1993, Off-Normal Report: Inadequate Waste Management Controls of 2706-T Hazardous Waste Storage Pad, RL-WHC-TPLANT-1992-0019, Westinghouse Hanford Company, Richland, Washington.

Mickelson, M. L., 1951, Annual Report of the Health Instruments Division, 1950, HW-21699, G.E. Hanford Company, Richland, Washington.

Mobley, W. N., 1950, Processing of Special Low-Level Material - T Plant Only, HW-19716, G.E. Hanford Company, Richland, Washington.

Norton, S. H., "Completion of 2706-T Operational Readiness Review," (Memo to G. W. Faulk, et al., dated June 28, 1993), Westinghouse Hanford Company, Richland, Washington. 
0'Toole, K., "Hanford Tests Put Gas Into Air," Tri-City Herald, April 10, 1986, p. Al-2, Richland, Washington.

Ortega, M. A., 1993, Operating Specifications for the T-Plant Facility, OSD-D-187-00008, B-0, Westinghouse Hanford Company, Richland, Washington.

Paas, H. J., and W. Singlevich, 1950, Radioactive Contamination in the Environs of the Hanford Works for the Period October, November, December 1949, HW-17003, G.E. Hanford Company, Richland, Washington.

Paas, H. J., and J. K. Soldat, 1951, Summary of Measurements for the Activity Density From I-131: For the Period September 1950 to July 1951, HW-21891, G.E. Hanford Company, Richland, Washington.

Packer, G. V., and W. C. Schmidt, 1952, Recycle of 231 Building Supernates to 224-T Building - Relationship to " $T$ " and "S" Plant, HW-25396,

G.E. Hanford Company, Richland, Washington.

Parker, H. M., 1945, Proposed Revision of Tolerances for I-131, HW-7-3042, Hanford Engineer Works, Richland, Washington.

Parker, H. M., 1945, Xenon and Iodine Concentrations in the Environs of the $T$ and $B$ Plant, HW-7-3005, Hanford Engineer Works, Richland, Washington.

Parker, H. M., 1946, Tolerable Concentrations of Radio-Iodine on Edible Plants, HW-7-3217, Hanford Engineer Works, Richland, Washington.

Parker, H. M., 1946, Tolerance Dose Interpretation of Permissible Daily Dose, DUH-12,744, Hanford Engineer Works, Richland, Washington.

Parker, H. M., 1947, Action Taken on the Spot Contamination in the Separations Plant Areas, HW-07920, G.E. Hanford Company, Richland, Washington.

Parker, H. M., 1948, Effect of Dissolver Off-Gas Scrubbers on Required Cooling Time, HW-10568, G.E. Hanford Company, Richland, Washington.

Parker, H. M., 1948, Progress Report on Action Taken on the Spot Contamination in the Separations Plant Areas, HW-08624, G.E. Hanford Company, Richland, Washington.

Parker, H. M., 1948, Status of Iodine Contamination - Proposed Increase of Cooling Time, HW-09394, G.E. Hanford Company, Richland, Washington.

Parker, H. M., 1950, Feasibility of Reduction of Cooling Time - Separations Process, HW-18409, G.E. Hanford Company, Richland, Washington.

Parker, H. M., 1950, Subject: Reduction of Decay Cooling Period, HW-18567, G.E. Hanford Company, Richland, Washington.

Parker, H. M., 1951, Quarterly Progress Report, Research and Development Activities, January - March 1951, G.E. Hanford Company, Richl and, Washington. 
Parker, H. M., 1951, Quarterly Progress Report, Research and Development Activities for April - June 1951, HW-21511, G.E. Hanford Company, Richland, Washington.

Parker, H. M., 1951, Radiological Sciences Department, Quarterly Progress Report, Research and Development Activities, July - September 1951, HW-22576, G.E. Hanford Company, Richland, Washington.

Parker, H. M., 1954, Status of Ground Contamination Problem, HW-33068, G.E. Hanford Company, Richland, Washington.

Patterson, J. W., "Approval to Receive and Bury Three Mile Island Submerged Demineralizer System Liners," (Internal memo 46000-83-035, dated February 17, 1983), Rockwell Hanford Operations, Richland, Washington.

Peters, G. F., 1953, Unitization Report: " $T$ " Plant Process Ventilation Improvements, Project AEC-IR-138, G.E. Hanford Company, Richl and, Washington.

Pike, S. T., "Letter to R. LeBaron, Chairman, Military Liaison Committee," dated April 5, 1950, U.S. Atomic Energy Commission, Washington, D.C.

"Plant Activities Support Mission," Hanford Reach, January 4, 1993, p. 5, Westinghouse Hanford Company, Richland, Washington.

Poucher, F. W., and W. P. Ingalls, 1955, Feasibility Report: Installation of the 231 Building Isolation Process in 224-T, HW-39871 RD, G.E. Hanford Company, Richland, Washington.

"Project Financial and Completion Report, Project No. M-757," dated June 27, 1951, G.E. Hanford Company, Richland, Washington.

Roberts, L. W., 1991, Unusual Occurrence Report: Solvent Spill at 2706-T, RL-WHC-TPLANT-1991-1011, Westinghouse Hanford Company, Richland, Washington.

Roberts, R. E., 1958, History of Airborne Contamination and Control, HW-55569 RD, G.E. Hanford Company, Richland, Washington.

Roe, P. I., "Hanford's Mission Helps 01d Facility Get New Lift," Hanford Reach, August 2, 1993, p. 8, Westinghouse Hanford Company, Richland, Washington.

S Division, 1951, Request for Appropriation M-606: Underwater Repair Facilities Buildings 221- $T$ and B, G.E. Hanford Company, Richl and, Washington.

Schlemmer, F. C., 1949, Events of Importance for Week Ending December 7, 1949, GEH-26643, U.S. Atomic Energy Commission, Richland, Washington.

Schmidt, W. C., 1954, Production Test 221-T-19: Reduction of Time Cycle in Dissolver Section, HW-34253, G.E. Hanford Company, Richland, Washington. 
Schmidt, W. C., 1955, Addendum to Production Test 221-T-19: Reduction of Time Cycle In Dissolver Section, HW-35055, G.E. Hanford Company, Richland, Washington.

Schure, S. F., 1950, Request for Appropriation - Rearrangement of F-Cell Equipment, Buildings 224- T-B, HW-14809, G.E. Hanford Company, Richland, Washington.

Schwartz, L. D., 1991, T-Plant Decontamination and Repair Facilities, SD-SQA-CSA-20104, (CSAR 86-007), Westinghouse Hanford Company, Richland, Washington.

Semmens, L. S., 1993, T-Plant Safety Analysis Report, WHC-SD-CP-SAR-007, Rev. 1, Westinghouse Hanford Company, Richland, Washington.

Seymour, F. P., 1947, Permissible Plutonium Content of Stack Exhaust Air, HW-07780, G.E. Hanford Company, Richland, Washington.

Short, M. L., 1960, Radiation Occurrence No. 8, G.E. Hanford Company, Richland, Washington.

Singlevich, W., 1948, Radioactive Contamination in the Columbia River and in the Air and Radiation Levels in the Air at Hanford Works and Vicinity for 1945, 1946, 1947 and Early 1948, HW-09871, G.E. Hanford Company, Richl and, Washington.

Sivula, C., "Declassified Report Sheds Light on 'Green Run'," Tri-City Herald, August 28, 1992, p. A7, Richland, Washington.

Sivula, C., "Dose Panel Raises Iodine Count 70\%," Tri-City Herald, October 9, 1992, p. Al, Richland, Washington.

Smith, J. M., 1950, Hanford Works Stacks - Construction and Usage, HW-18143, G.E. Hanford Company, Richland, Washington.

Soule, H.F., and Taylor, R.E., "Review of Silver Reactor Performance in the Separations Facilities," HW-27580 (Richland, WA: G.E. Hanford Co., March 27, 1953).

Stainken, F. A. R., 1948, Stack Gas Conference - Washington, DC, HW-10956, G.E. Hanford Company, Richland, Washington.

Steele, K. D., "In 1949 Study, Hanford Allowed Radioactive Iodine Into Area Air," Spokesman Review-Spokane Chronicle, dated March 6, 1986, p. A6, Spokane, Washington.

Szulinski, M. J., 1950, Elimination of Iodine from Canyon Building Exhaust Air, HW-19609, G.E. Hanford Company, Richland, Washington.

Szulinski, M. J., 1974, The Hanford Decontamination Facility, ARH-SA-181, Atlantic Richfield Hanford Company, Richland, Washington.

Tabb, F. G., 1947, Special Hazards Incident Investigation, Incident \#68, Class I, G.E. Hanford Company, Richland, Washington. 
Thorburn, R. C. 1947, Detection of Plutonium in Desert Flora, HW-07002, G.E. Hanford Company, Richland, Washington.

Turner, L. D., 1946, Vegetation Contamination for Second Quarter of 1946, HW-3-3603, Hanford Engineer Works, Richland, Washington.

Turner, L. D., 1946, Vegetation Contamination for Period July 2, 1946 to August 31, 1946, HW-3-5055, G.E. Hanford Company, Richland, Washington.

Turner, L. D., 1947, The Trend of Contamination Observed in the Air, Columbia River, and Vegetation at the Hanford Engineer Works for 1946, HW-3-5402, G.E. Hanford Company, Richland, Washington.

Turner, L. D., 1947, Vegetation Contamination for Period September 3, 1946 to December 31, 1946, HW-3-5521, G.E. Hanford Company, Richland, Washington.

Vanderbeek, J. W., 1955, Radiological Sciences Department Investigation, Radiation Incident, Class I, No. 432, HW-36563, G.E. Hanford Company, Richland, Washington.

Vanderbeek, J. W., 1956, Radiological Sciences Department Investigation, Radiation Incident Class I, No. 553-C, HW-41074, G.E. Hanford Company, Richland, Washington.

"Village Faces Boom with Plant Expansion," Richland Villager, August 14, 1947, p. 1, Richland, Washington.

Wagoner, J. D., "Award Fee Determination for Westinghouse Hanford Company (WHC), Contract No. DE-AC06-87RL10930, Evaluation Period Ending March 31, 1991," (Letter to T. M. Anderson, dated June 7, 1991, with attachment, "DOE-RL Performance Evaluation Board Report: WHC Performance During the Six-Month Evaluation Period Ending March 31, 1991"), U.S. Department of Energy, Richland Operations Office, Richland, Washington.

Waite, J. L., 1991, Tank Wastes Discharged Directiy to the Soil at the Hanford Site, WHC-MR-0227, Westinghouse Hanford Company, Richland, Washington.

Warner, R. S., "Decontamination of Stack Gases," (Memo to C. L. Wilson, dated June 4, 1948), U.S. Atomic Energy Commission, Washington, D.C.

Warner, R. S., "Stack Gas Working Group - Meetings," (Memo to R. B. Snapp, dated August 20, 1948), U.S. Atomic Energy Commission, Washington, D.C.

Wende, C. W. J., 1949, Pile Operation at Higher Power, HW-13184, G.E. Hanford Company, Richland, Washington.

WHC, 1992, FY 1993 Fiscal Year Work Plan, WHC-FYWP-1993-WDS, Westinghouse Hanford Company, Richland, Washington.

WHC, 1992, "T-Plant Parking Lot Resurfacing and Entry Way Addition," Project C-134, Westinghouse Hanford Company, Richland, Washington. 


\section{WHC-MR-0452, ADDENDUM 1}

WHC, 1993, "Change Request \#SWD-93-58: WDS 1993 FYWP Revision 1," (Correspondence \#9353246), Westinghouse Hanford Company, Richland, Washington.

WHC, 1993, "Hanford Facility Dangerous Waste Part A Permit Application, Revision 1, for the T-Plant Complex," Westinghouse Hanford Company, Richland, Washington.

WHC, 1993, Waste and Decontamination Services 1994 Fiscal Year Work Plan WBS 1.2.3, WHC-SP-1030, Westinghouse Hanford Company, Richland, Washington.

Whitney, D., "'49 Iodine Releases Larger, says DOE," Tri-City Herald, May 4, 1989, p. Al, Richland, Washington.

Wiater, P. J., 1967, CPD Special Services Shippingport Fuels Report, IS0-915, I sochem, Inc., Richland, Washington.

Wiater, P. J., "Monthly Equipment Progress Reports," January - December 1969, Atlantic Richfield Hanford Company, Richland, Washington.

Wilson, R. H., 1955, Addendum to Radiological Sciences Department Investigation, Radiation Incident, Class I, No. 425 and No. 494, $H W-36034-A D, G . E$. Hanford Company, Richland, Washington.

Windsheimer, W. W., 1948, History of the Reactivation of 100 B-Pile, HW-11374, G.E. Hanford Company, Richland, Washington.

Wisehart, D. E., and F. E. Adley, 1953, A Study of T-Plant Stack Particulates, HW-28828, G.E. Hanford Company, Richland, Washington.

Wojtasek, R. D., "Auxiliary Requirement for T-Plant During SDS Liner Transloading Operations," (Internal Memo 65410-82-136, dated September 3, 1982), Rockwell Hanford Operations, Richland, Washington.

Work, J. B., 1948, Decontamination of Separation Plant Ventilation Air, HW-11529, G.E. Hanford Company, Richland, Washington.

Work, J. B., 1951, Efficiency Evaluation of the Dissolver Cell Silver Reactor and Fiberglass Filter, HW-19898, G.E. Hanford Company, Richland, Washington.

Yoder, R. A., and J. R. LaRiviere, 1983, 224-T Building Safety Analysis Report, SD-HS-SAR-003, Rev. 2, Rockwell Hanford Operations, Richland, Washington. 
WHC-MR-0452, ADOENDUM 1

DISTRIBUTION

\section{Number of Copies}

OFFSITE

1

Los Alamos Technical Associates

8633 Gage Bivd.

Kennewick, Washington 99336

\section{J. A. Reddick}

\section{QNSITE}

8

\section{U.S. Department of Energy.} Richland Operations Office

T. H. Davies

$T 3-28$

R. F. Guercia

$R 3-80$

J. M. Hennig

R3-80

J. R. Hunter

R3-81

J. K. Schmitz

A5 -18

78

Westinghouse Hanford Company

M. V. Berriochoa

83-30

R. J. Bliss

D. M. Bogen

R. J. Bottenus

B3-04

S6-65

D. B. Cartmell

N3-13

R3-56

P. J. Crane

T3-28

E. A. Cruz

D. R. Duncan

G. W. Faulk

M. S. Gerber (30)

N3-13

H5-33

$T 3-28$

R. L. Gilchrist

N1 $1-36$

R. J. Giroir

W. H. Hamilton, Jr.

D. G. Hamrick

i. L. He inemeyer

L5- 63

T4-05

N13-10

Só-15

1 $13-14$

F. A. Hewitt

$T 3-28$

K. L. Hladek

H5 -33

M. R. Ibatuan

1 $3-13$

H. G. Jasen

R. C. Johnson.

รо̄-17

T3-20

C. S. Krogness

L3-09

B. S. Kuntz

$33-25$

E. F. Mares

$33-14$ 
WHC-MR-0452, ADDENDUM 1

\section{DISTRIBUTION (cont.)}

ONSITE

Westinghouse Hanford Company (cont.)

M. M. McCarthy

H. E. McGuire

N3-13

W. J. McKenna

D. E. McKenney

E. P. Mertens

J. C. Midgett

J. A. Mortensen

B3-63

B3-30

N3-10

N3-13

J. A. Nielsen

N2-51

M. A. Ortega

L. F. Perkins Jr.

T3-28

N3-14

T3-28

D. R. Pyzel

$56-15$

J. G. Riddelle

T4-04

R. J. Roberts

T3-28

W. J. Sanderson

B5-26

W. Smith

J. M. Steffen

$B 3-35$

T3-28

$\mathrm{N} 1-47$

$T$. C. Synoground

T3-28

G. C. Triner

E. C. Vogt

T3-04

A. P. Williams

T5-50

T. L. Woodford

T3-28

M. S. Wright

T3-28

T3-28 

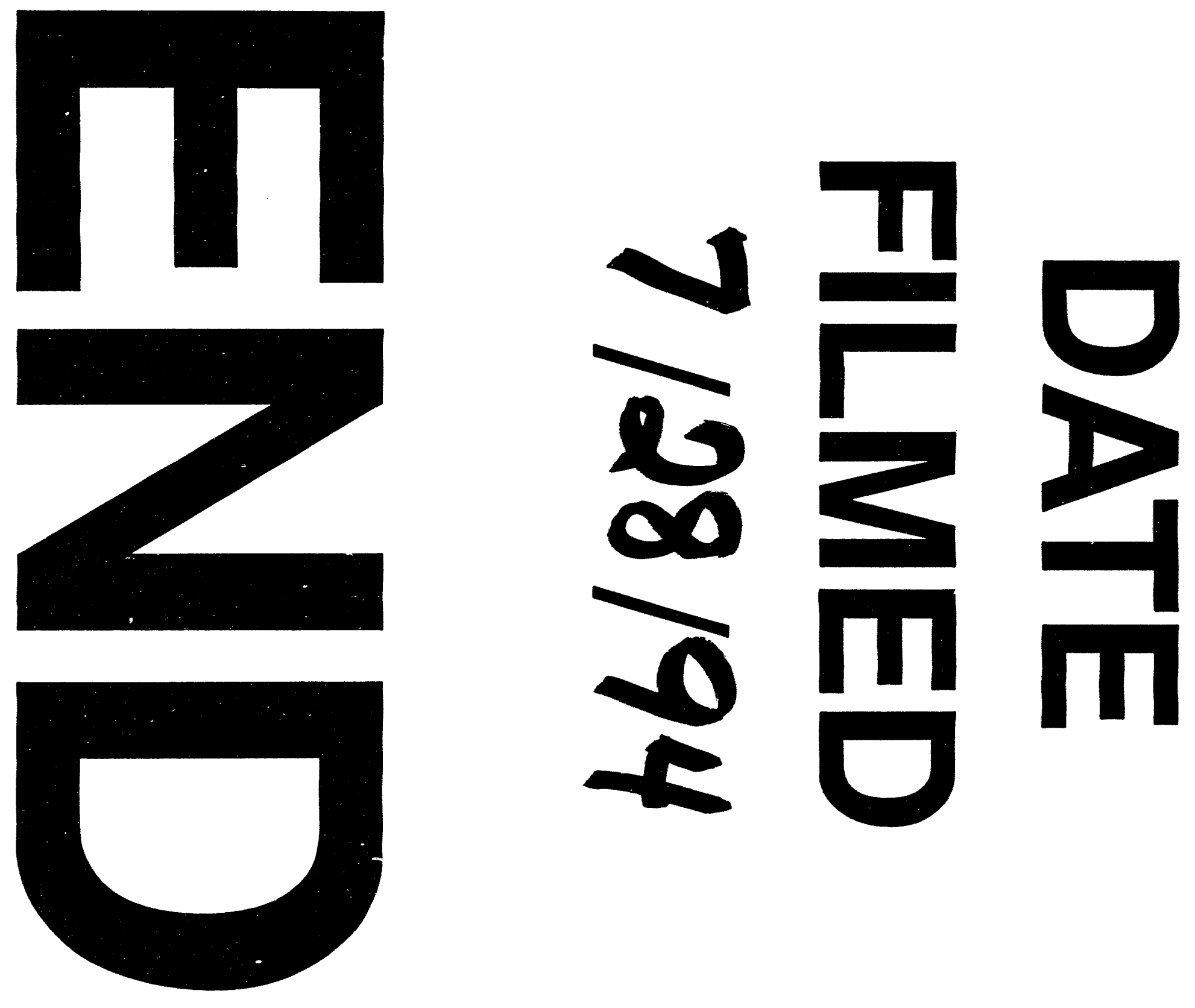


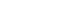

